\title{
Geoarchaelogical Study of the Roman Pietra Dell'Oglio Bridge at the Service of the Old Appian Way, Campania, Southern Italy
}

\section{Ugo Chiocchini $^{*}{ }^{(}$, Mariella De Piano², Mario Gaeta ${ }^{3}$, Erminio Pagliuca ${ }^{4}$, Nicola Polzone ${ }^{4}$ Fiammetta Sarmento ${ }^{4}$}

${ }^{1}$ Formerly Professor of Engineering Geology at the Università Degli Studi della Tuscia, Italy

${ }^{2}$ Dipartimento Di Ingegneria Civile, Università Degli Studi Di Salerno, Salerno, Italy

${ }^{3}$ Dipartimento Di Scienze Della Terra, Sapienza Università Di Roma, Roma, Italy

${ }^{4}$ Geoconsultlab, Manocalzati, Avellino, Italy

Email: *luca_chiocco@libero.it

How to cite this paper: Chiocchini, U., De Piano, M., Gaeta, M., Pagliuca, E., Polzone, N., \& Sarmento, F. (2021). Geoarchaelogical Study of the Roman Pietra Dell'Oglio Bridge at the Service of the Old Appian Way, Campania, Southern Italy. Archaeological Discovery, 9, 223-258.

https://doi.org/10.4236/ad.2021.94012

Received: July 11, 2021

Accepted: September 24, 2021

Published: September 27, 2021

Copyright $\odot 2021$ by author(s) and Scientific Research Publishing Inc. This work is licensed under the Creative Commons Attribution International License (CC BY 4.0).

http://creativecommons.org/licenses/by/4.0/

\begin{abstract}
The Pietra dell'Oglio bridge is the only Roman infrastructure that crosses the Ofanto River between Mirabella Eclano (Aeclanum in Campania) and Venosa (Venusia in Basilicata), just near the border between Campania and Basilicata. The bridge was built on a substrate consisting of the stable middle Miocene Cerreta-Bosco di Pietra Palomba Sandstone (ACP) and where the Ofanto River valley is narrower. The current state of the bridge shows that 18 architectural and structural elements are original, 12 were restored, 1 was modified, 4 were reconstructed, and 4 were added in the last century. The original architectural and structural elements (ASEs) are built by the technique of opus quadratum and opus incertum using the pebbles of the Ofanto River and ashlars of phytoclastic travertine and ACP Sandstone cemented by very hard mortar. The opus incertum technique and its use for many bridges in Italy and France suggest that the Pietra dell'Oglio bridge was built between the II and I century BC at the service of a very important public road. The present research is allowed to identify the Pietra dell'Oglio bridge with the Pons Aufidi related to the old Appian Way layout between Mirabella Eclano and Venosa and contributes to improving the knowledge of Roman bridge engineering, particularly in Campania.
\end{abstract}

\section{Keywords}

Geoarchaeology, Pietra Dell'Oglio Bridge, Old Appian Way, Opus Incertum, Campania 


\section{Introduction}

Bridges are infrastructures of primary importance in the history of humanity because they connect the peoples on Earth, facilitating communication between them and allowing the exchange of civilizations and cultures. Bridges are essential for ancient and modern cities and for the road network, to overcome rivers and smaller waterways. They were built in Roman times by valid designers and civilian and military workers, often in conditions of difficult logistic and complex morphological situations, by boats and ships, wood, masonry, and mixed type of materials with masonry substructure and wooden superstructure.

Initially, the task of building roads and bridges was entrusted to magistrates such as the censors, deprived of imperium, tribunes of the plebs, aedili, legacies of the proconsuls. Subsequently, the impressive construction of roads and bridges in the II and I centuries BC created a complex and expensive network of urban and territorial infrastructures because they required, in addition to construction, restoration, reconstruction and maintenance. The road network was attributed to a particular and extraordinary magistrate: the Curator viarum, the governance between the praetorship and the consulate. According to Tito Livio from the II century BC the contract institute was applied (locatio conductio operis) to organize the works for the roads and bridges to tenant entrepreneurs (conductores viarum).

The Roman roads were classified according to their importance, as reported by the surveyor Siculus Flaccus (Adams, 2011).

$>$ Public roads were built at the expense of the State and with the name of the builder.

Strategic roads were built by the army at its expense.

$>$ Secondary roads were built by villages ( $p a g i$ ).

Private roads were built by land and house owners.

Different bridges were needed for the construction of the old Appian Way, a public road also known as Regina viarum, whose construction began in 312 BC at the request of the censor Appio Claudio Cieco to connect Rome to the port of Brindisi on the Adriatic Sea in Puglia. The enormous importance of this consular road on the connective, commercial and military lines was underlined by Pisani Sartorio (2003), while Chiocchini et al. (2016) faced a little known aspect of Regina viarum, contributing to the identification of its layout between Mirabella Eclano (heir of the ancient Aeclanum, in the middle valley of the Calore River in Campania) and Venosa (Venusia, Latin colony founded in 291 BC in Basilicata) located in the Campania and Basilicata Apennine (Figure 1).

The bridge over the Ofanto River (Flumen Aufidus), also reported in the Tabula Peutingeriana as Pons Aufidi, is a crucial issue in determining where the layout of the old Appian Way between Mirabella Eclano and Venosa had to cross this river in the area between Conza della Campania (heir of the ancient Compsa) and the Santa Venere bridge (SVB) (Figure 2). It should be noted that near Conza della Campania there was another Roman bridge over the Ofanto 


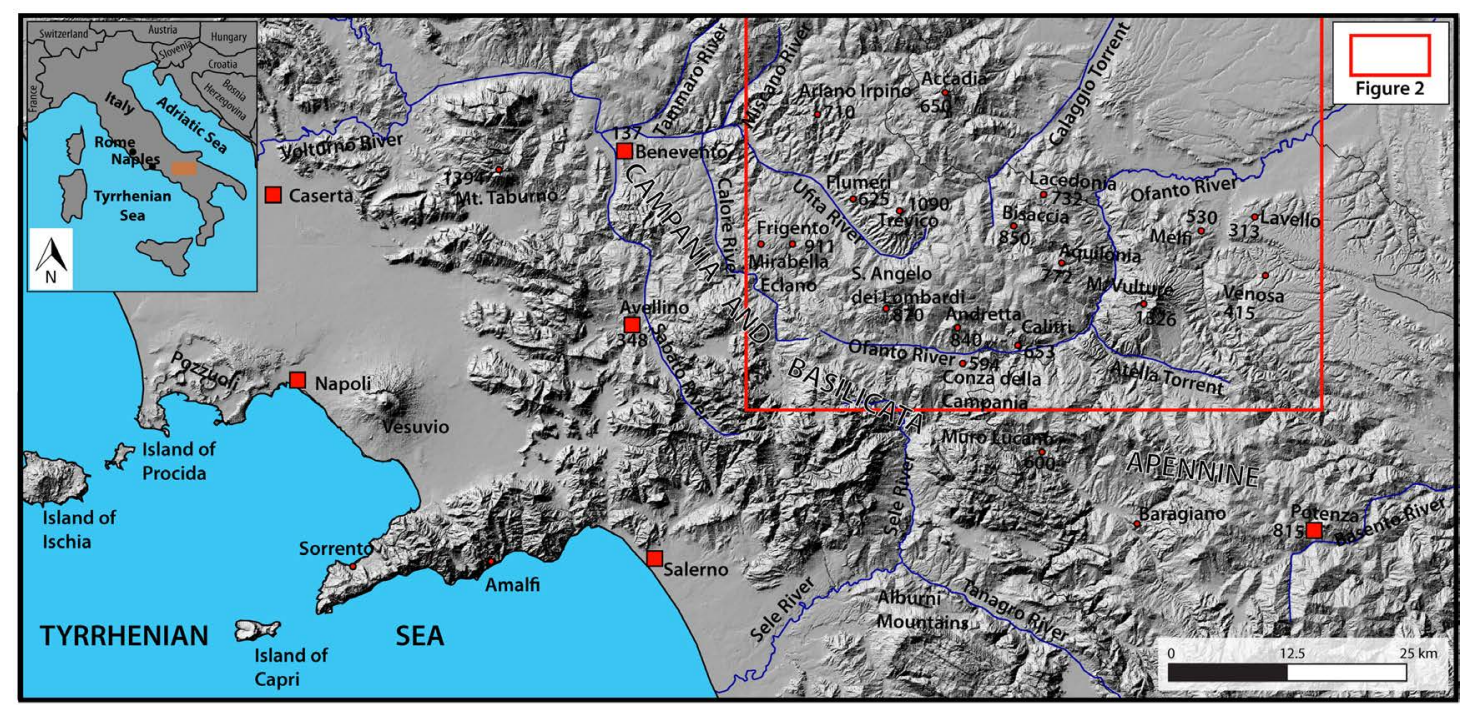

Figure 1. Digital terrain model of the Campania and Basilicata Apennine with the location of cities (red squares), small towns (small red circles), streams, and Figure 2 (red rectangle).

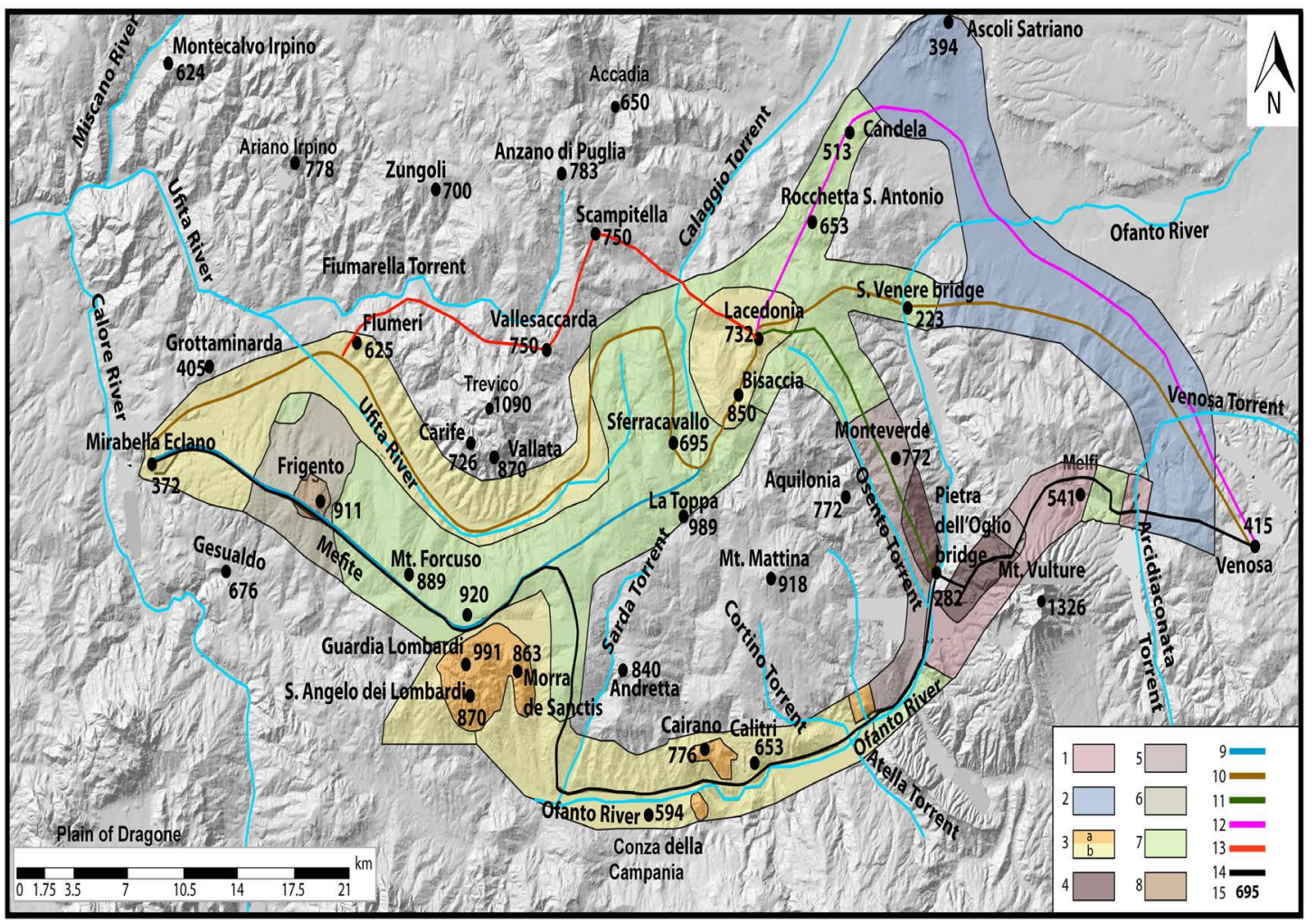

Figure 2. Digital terrain model illustrating the geological setting of the layouts proposed by the Authors for the old Appian Way between Mirabella Eclano (Aeclanum) and Venosa (Venusia). 1) tuffs and lavas (Pleistocene); 2) gravels, sands and clays (Pliocene-Pleistocene); 3) Ruvo del Monte Synthem: conglomerates (a); sands and clays (b) (lower Pliocene-upper Pliocene); 4) Cerreta-Bosco di Pietra Palomba Sandstone (middle Miocene); 5) Numidian Flysch (lower Miocene); 6) calcareous member of the Varicolored Clays Formation: turbidite calcarenites and marls (lower Miocene); 7) Varicolored Clays Formation: clays, marls, marly and siliceous limestones, turbidite calcarenites (Cretaceous-lower Miocene); 8) Flysch galestrino: clays, marls, marly and siliceous limestones (lower Cretaceous); 9) 10) 11) 12) 13) hypothesis of the northern layouts; 14) hypothesis of the southern layout according to Chiocchini et al. (2016); 15) altitude m asl. 
River, of which only one pier survived, at present submerged in the basin created by the Conza della Campania dam (Aveta et al., 2012; Chiocchini et al., 2016).

Two hypotheses have been proposed for the layout of the old Appian Way between Mirabella Eclano and Venosa: 1) the nortnern layouts (9, 10, 11, 12, 13 in Figure 2), which crossed the Ofanto River by the SVB, even if this bridge is not really of Roman age, as specified later (Pratilli, 1745; Mommsen, 1848; Jannacchini, 1889; Grasso, 1893; Guarini, 1909; Ashby, 1916-1917; Iacobone, 1935; Lugli, 1952, 1963; Castagnoli, 1969; Alvisi, 1970; Radke, 1981; Stazio, 1987; Quilici, 1989, 2004; Flammia, 1995; Romito, 1995; Johannowsky, 1996; Tazzi, 1998; Fornaro, 2000; Della Portella, 2003; De Luca, 2003; Morano, 2003; Cera, 2011; Ceraudo, 2011; Castrianni, 2013; Del Lungo, 2013; Lariccia, 2015; Marchi \& Ferlazzo, 2015; Ceraudo, 2019); 2) the southern layout (14 in Figure 2), which crossed the Ofanto River by the Pietra dell'Oglio bridge (POB) (Mannert, 1823; Lenormant, 1883; De Lorenzo, 1906; Buglione, 1929; Grassi, 2013). This latter hypothesis has been deepened, updated, and documented by Chiocchini et al. (2016) with new widely evident data that demonstrate how this layout is the shortest and most convenient in terms of design and construction, and therefore the most reliable alternative. The hypothesis of the southern layout with the POB was also adopted by Vistoli (2019), while according to Marchi (2019a, 2019b), who deals with the layout of the old Appian Way in Basilicata mentioning the specific arguments of Chiocchini et al. (2016), it is doubtful whether the Pons Aufidi is the SVB or the POB.

As for the POB, it should be noted that there is no specific study aimed at describing its current state, original architectural and structural elements and the materials used for the construction, but only scarce, short and inaccurate information is available on this bridge. In fact, De Lorenzo (1906) and the Gardner Collection (Castrianni, 2013) show two fairly clear photos of the bridge, taken from the left bank of Ofanto River, respectively NW down-stream and NW upstream. Guarini (1909) and Iacobone (1935) propose two small and unclear photos of the Pietra dell Olio bridge (later changed to Oglio) seen from NE (downstream). Buglione (1929) shows a partially unclear photo of the bridge that does not allow to establish the point where it was taken. Gazzola (1963) indicates that the bridge is divided into six large arches and only the two external ones and the piers date back to the Roman age. Unfortunately, there is no evidence of the existence of structures of the Roman age, and in the very small picture, the bridge cannot be seen clearly and neither how it is oriented. O'Connor (1993) incorporates the data of Gazzola (1963). Aveta et al. (2012), who studied the historical bridges of Campania with reference to 26 Roman bridges, among which 4 located in the province of Avellino (Santo Spirito bridge in Casalbore, Pietra dell'Oglio bridge, Annibale's bridge in San Mango sul Calore, Conza della Campania bridge), describe the POB consisting of four asymmetric arches, of which the first and third are semicircular, while the intermediate one is a reconstructed lowered arch. Furthermore, the fourth arch "had previously been covered for the recon- 
struction of the road to Monteverde, today visible with difficulty". However, this arch does not exist, as specified later. Very short references to the bridge are described by Troncone (2013), who indicates the presence of four round arches, and by Carluccio (2013), according to which the bridge is built by the opus incertum technique. Vistoli (2019), in the context of two itinerary stations of the old Appian Way between Aeclanum and Venusia, also provides the description of the POB which, however, is incomplete and insufficient as regards the geomorphological characteristics of the site, the structural and architectonic elements and the type of materials used for the construction of the bridge, in particular the quality of the recent mortar and the dated one. Marchi (2019a, 2019b) refers to the data of the POB according to Vistoli (2019).

The research is framed in the activity carried out by the Associazione Nazionale per gli Interessi del Mezzogiorno d'Italia (ANIMI) - Società Magna Grecia in relation to the interdisciplinary work focused on the study of archaeological sites and their environmental context, and the techniques of Geoarchaeology (Rapp \& Hill, 1998; Pollard, 1999; Ghilardi \& Desruelles, 2009; Shahack-Gross, 2017; Gilbert, 2017; Gençer \& Turan, 2017; Leonardi, 2017; Cortéz Pérez et al., 2018; Shillito et al., 2019) have been applied in order to: 1) illustrate the geological and geomorphological setting of the $\mathrm{POB}$ area; 2) describe the current state of the $\mathrm{POB}$, its original architectural and structural elements, and their raw materials, to identify the possible construction period; 3) establish whether the POB is the Pons Aufidi of the old Appian Way; 4) improve the knowledge on the construction techniques of Roman bridges, particularly in Campania.

\section{Location of the Study Area}

The POB, located in the extreme southeastern sector of the municipality of Aquilonia (province of Avellino, Campania) close to the border with Basilicata in Section IV NO of Sheet 187 Melfi at scale 1:25,000 (coordinates of southeastern entrance of the bridge: $40^{\circ} 57^{\prime} 54^{\prime \prime}$ latitude $\mathrm{N}$ and $15^{\circ} 33^{\prime} 50^{\prime \prime}$ longitude $\mathrm{E}$ ), was used initially to connect Monteverde to its railway station, successively also to the national road SS 401 dir. The bridge crosses, with a NW-SE orientation, perpendicularly the Ofanto River ( $281 \mathrm{~m}$ asl), flowing from SW to NE, at the height of the Mt. Teuto (598 m asl)-Bosco di Pietra Palomba ridge (514 - $318 \mathrm{~m}$ asl) and Foggiano (424 m asl) (Figure 2 and Figure 3).

\section{Materials and Methods}

The bridge study operations were developed in four phases. The first phase was dedicated to the acquisition of historical data from the Municipality of Aquilonia, the Engineer of Avellino and the State Archive of Napoli.

The second phase included the following activities. 1) The definition of the geological and geomorphological setting of the POB by the field checking of the survey by Centamore et al. (1971) and updating it to the Sheet 451 Melfi of the Italian Geological Map at scale 1:50,000 (Istituto Superiore per la Protezione e la 
Ricerca Ambientale-Servizio Geologico d'Italia, in print-a). The color of the rocks was defined by the Rock-Color Chart (Geological Society of America, 1991). 2) The execution of a) the partial cut of the weed and climbing vegetation that covers many bridge structures; b) a first material survey by the Professional BOSCH GLM 250 VF Laser Digital Distance Detector to define the current state of the architectural and structural elements of the bridge; c) a second material survey by a Laser Scanner Focus ${ }^{3 \mathrm{D}} \mathrm{S}$ to check in detail the dimensions of these elements, and d) the aerial video shooting using the aircraft with remote controlled pilot (drone models DJI Phantom 4 and Phantom 4 PRO). 3) The analysis of the masonry textures of the original architectural and structural elements and their construction techniques. 4) The acquisition of 15 samples of the materials used to build the bridge, 10 of which from the outcrops (alluvial pebbles, phytoclastic travertine, sandstone, which was extracted by the HILTI electric core drilling machine), 2 phytoclastic travertine samples from two arches of the bridge and 3 samples of mortar from the latter and from a pier.

The following investigations were carried out in the third phase. 1) An electrical resistivity tomography to define the thickness of alluvial deposits and the underlying substrate, performed by the geo-resistivity-meter M.A.E. A6000SE, producing the energization by means of electrodes driven into the ground with unit spacing of $2 \mathrm{~m}$ and simultaneously acquiring the apparent resistivity (pa) and soil chargeability (I.P.). The data recording was carried out according to the DipoleDipole-Axial scheme, which allows to better read the lateral discontinuities, and for the data processing the Res2Dinvi software was used. 2) A detailed inspection was carried out in the SVB area, located about $15 \mathrm{~km}$ north of the POB, to verify the presence of remains attributable to a Roman age bridge.

The fourth phase was dedicated to the following laboratory analyses and tests (Marra et al., 2015; Columbu et al., 2018; Sitzia, et al., 2020). 1) The mineralogical analysis of the mortar by the X-ray powder diffractometer Siemens D5000 with Gragg-Brentano and radiation $\lambda_{\mathrm{KaCu}}$ geometry, in which the crystalline powder under examination is placed on a flat sample holder with a scan range of $2.5^{\circ}<$ $2 \theta<140^{\circ}$.2) The investigation of the samples of stone materials and mortar by the polarized microscope Zeiss Axioskop on $30 \mu \mathrm{m}$ thin sections. The modal analysis of the mortar samples by point counter on 300 points for each thin section. 3) The recognition of particular forms of calcite in the mortar by the FEI Quanta-400 Scanning Electron Microscopy (SEM). 4) The tests to determine the dry masses $\left(m_{d}\right)$ at $105^{\circ} \mathrm{C} \pm 5^{\circ} \mathrm{C}$ of the cubic samples $(10 \times 10 \times 10 \mathrm{~mm})$ of mortar were carried out by the analytical balance Sartorius Entris153-1s. The real volume $\left(V_{T}\right)$ and bulk volume $\left(V_{b}\right)$ were determined by the Regnault pycnometer for solids with cap $100 \mathrm{ml}$. The bulk volume $\left(V_{b}\right)$ was calculated as:

$$
V_{b}=\left[\left(m_{w}-m_{h}\right) / \rho_{w 25^{\circ} \mathrm{C}}\right] \times 100
$$

where $m_{w}$ is the wet mass, $m_{h}$ is the hydrostatic mass of the wet sample, and $\rho_{w 25^{\circ} \mathrm{C}}$ is the density of the water $\left(0.9970 \mathrm{~g} / \mathrm{cm}^{3}\right)$ at temperature of $25^{\circ} \mathrm{C}$. The ap- 
parent density $\left(\rho_{b}\right)$ and the real density $\left(\rho_{I}\right)$ were computed as:

$$
\rho_{b}=m_{d} / V_{b} ; \rho_{r}=m_{d} / V_{r} .
$$

5) The preparation of four cores of ACP Sandstone for its mechanical characterization according to the recommendations of ASTM (2014) and I.S.R.M. (1994): verification of the perpendicular position of the base faces of cores with respect to their axis; checking of the lateral surface of the cores which must be smooth; measurement of the length and diameter of the cores as the average of two diameters orthogonal to each other. 6) The execution of two uniaxial compression tests and two tensile tests on the four cores by a Controls brand press with controlled load.

As for the construction of Roman bridges, we refer to the monumental works of O'Connor (1993) and Galliazzo (1995), which are still up today the most comprehensive, in-depth, and detailed ones (Cortéz Pérez et al., 2018; Inglese \& Paris, 2020). In fact, these two Authors describe the historical, architectural, structural, archaeological, typological, and planning aspects (from the works of foundation to the walking floor, the furnishings, the defenses) and methodology on the possibility of dating, respectively, about 330 and 1560 bridges in different areas of Europe and the Middle East. As for the architectural elements, reference is made to the equally monumental work of Lugli (1957), still considered one of the most complete and precise studies on this topic (Adams, 2011; Aveta et al., 2012; Inglese \& Paris, 2020). Finally, the study by Aveta et al. (2012) provided valuable support for the conservation status and construction techniques of the historic bridges in Campania.

\section{Geological and Geomorphological Setting}

The study area is located in the middle valley of the Ofanto River hosted in a tectonic depression oriented west-east inside the Campania and Basilicata Apennine, mainly consisting of clays, sands and conglomerates of the Pliocene Ruvo del Monte Synthem, and subordinately of Mesozoic-Cenozoic formations (Figure 1 and Figure 2) (Sheet 450 S. Angelo dei Lombardi and Sheet 451 Melfi of the Geological Map of Italy at scale 1:50,000) (Istituto Superiore per la Protezione e la Ricerca Ambientale-Servizio Geologico d'Italia, in print-a, in print-b). This area is in contact with the western edge of the Mt. Vulture's volcanic complex (Figure 2) with geochemical characteristics similar to those of the Campania Province (affinity with potassium and ultra-potassium series), active with pyroclastic deposits and lava flows during middle Pleistocene between 0.740 and $0.140 \mathrm{Ma}$ (Sheet 450 S. Angelo dei Lombardi and Sheet 451 Melfi of the Geological Map of Italy at scale 1:50,000) (Istituto Superiore per la Protezione e la Ricerca AmbientaleServizio Geologico d'Italia, in print-a, in print-b). Figure 3 shows the geological map of the bridge area in the section IV NO of the Sheet 187 Melfi at scale 1:25,000 of the Military Geographic Institute, and Figure 4 the corresponding geological section. The stratigraphic succession includes the following formations (Figure 3): the Cretaceous-lower Miocene Varicolored Clays Formation (red, green, 
gray clays, marls, marly and siliceous limestones, turbidite calcarenites with chaotic structure; AVR); the lower Miocene calcareous member of the AVR (turbidite calcarenites and marls; $\mathrm{AVR}_{1}$ ); the lower Miocene Numidian Flysch (well cemented turbidite medium-coarse quartz-arenites of dark yellow orange color 10 YR 6/6 with thick and very thick beds; FYN); the middle Miocene (middle-upper Serravallian) Cerreta-Bosco di Pietra Palomba Sandstone (ACP). This is the most

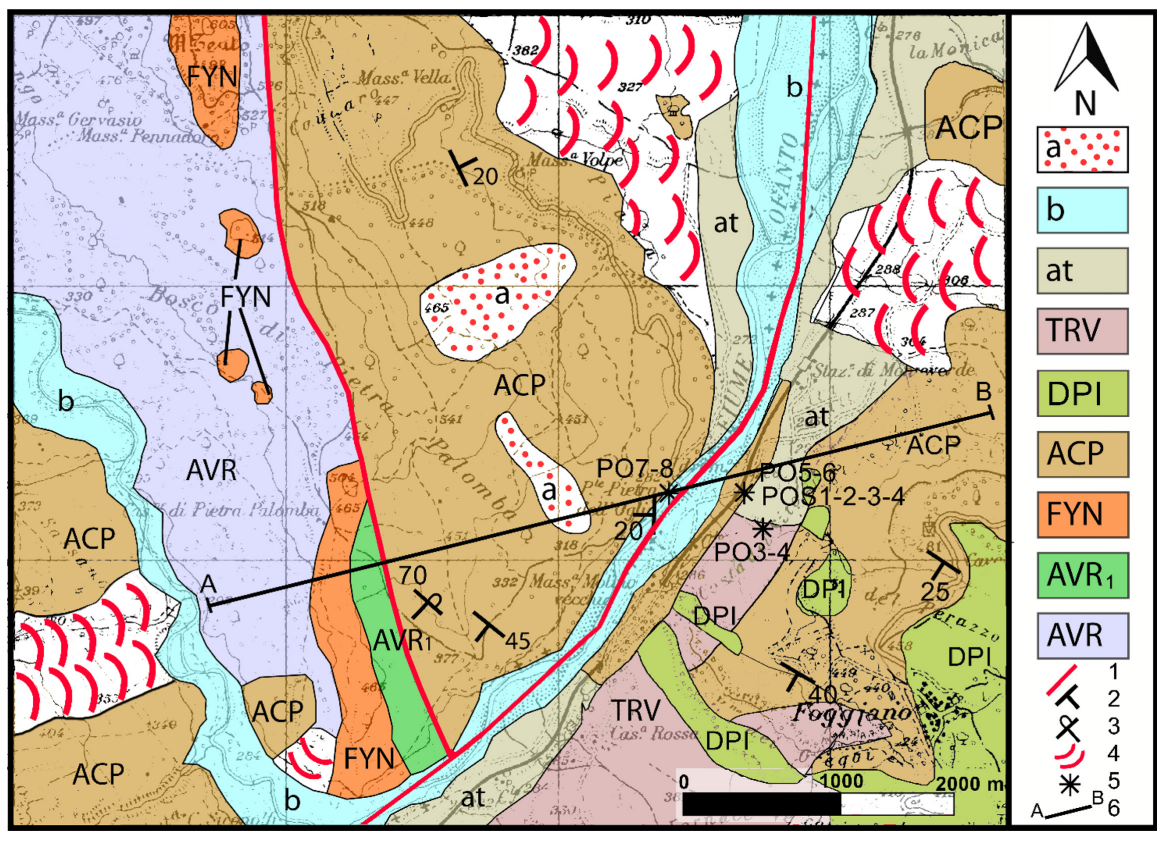

Figure 3. Geological map of the area of the POB. The double dashed lines indicate the unpaved secondary roads. a, slope deposits (Holocene); b, alluvial deposits (HoloceneActual); at, terraced alluvial deposits (upper Pleistocene-Holocene); TRV, terraced polymictic gravels and phytoclastic travertines (middle-upper Pleistocene); DPI, pyroclastic deposits (middle-upper Pleistocene); ACP, Cerreta-Bosco di Pietra Palomba Sandstone (middle Miocene); FYN, Numidian Flysch (lower Miocene); $\mathrm{AVR}_{1}$, calcareous member of the Varicolored Clays Formation (lower Miocene); AVR, Varicolored Clays Formation (Cretaceous-lower Miocene); 1, normal fault; 2 , bed attitude; 3, overturned bed; 4, landslide; 5 , location of the samples for mineralogical, petrographic and strength analyses; 6 , trace of the geological section.

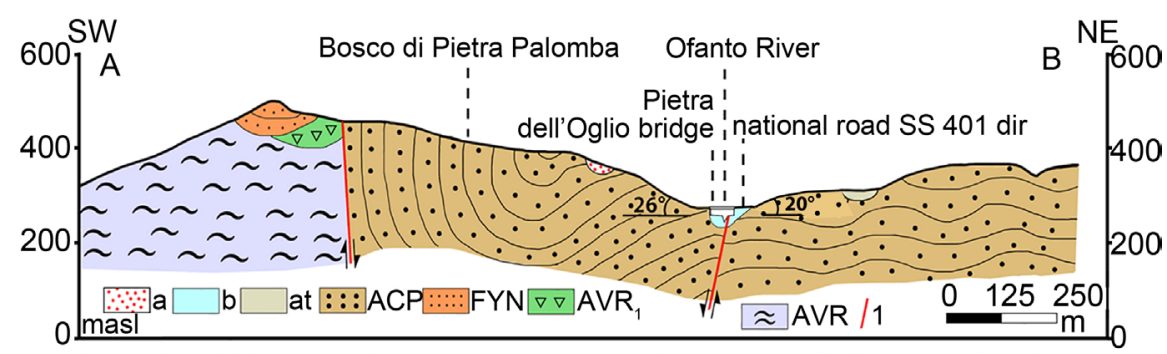

Figure 4. Geological section. b, alluvial deposits (Holocene-Actual); at, terraced alluvial deposits (upper Pleistocene-Holocene); ACP, Cerreta-Bosco di Pietra Palomba Sandstone (middle Miocene); FYN, Numidian Flysch (lower Miocene); $\mathrm{AVR}_{1}$, calcareous member of the Varicolored Clays Formation (lower Miocene); AVR, Varicolored Clays Formation (Cretaceous-lower Miocene); 1, normal fault. 
widespread formation, made up of turbidite medium-coarse sandstones of dark yellow orange color 10 YR 6/6 with characteristic diagenetic spheroids and thick and very thick amalgamated beds. These sandstones show a variable medium degree of cementation in the rock mass. Furthermore, there are pyroclastic and alluvial deposits. The former consists of juvenile ashes, ignimbrite deposits and polymictic heterometric sandy conglomerates with ash levels of the middle-upper Pleistocene (DPI). The alluvial deposits include three units. 1) The polymictic heterometric gravels and phytoclastic travertines (D'Argenio \& Ferreri, 1987, 1988; D'Argenio et al., 2013) or calcareous tufa (Pedley, 1990, 2009, 2014; Ford \& Pedley, 1996; Capezzuoli \& Gandin, 2004; Gandin \& Capezzuoli, 2008; Gandin, 2013; Capezzuoli et al., 2014; Imbriale, 2014) of white N 9 and very light gray $\mathrm{N} 8$ color, characterized by wavy and radiated structures, plant fragments of encrusted macrophytes, porosity, and scarcely evident bedding (TRV) of the middle-upper Pleistocene, that form a suspended terrace on the current valley bottom. 2) The polymictic heterometric gravels with poor sandy silty matrix, consisting of pebbles of marly and siliceous limestones, and calcarenites of light gray N 7 and dark gray N 3 - N 4 color with predominantly lamellar and spheroidal shapes, referred to the upper Pleistocene-Holocene terraced deposits (at) of the actual valley bottom. 3) The Holocene-Actual similar deposits (b) (Giannandrea, 2004; Istituto Superiore per la Protezione e la Ricerca Ambientale-Servizio Geologico d'Italia, in print-a). The electrical resistivity tomography, performed on the alluvial deposits according to the $64 \mathrm{~m}$ long trace A $B$ in Figure 5(a), highlighted 4 electro-layers (Figure 5(b)). The section of Figure 5(b) shows that the first layer, whose base is indicated by the wavy yellow line, is characterized by resistivity values of $20-70 \mathrm{ohm}$ and an average thickness of $1.50 \mathrm{~m}$. The second layer, delimited by the black line, has resistivity values of $100-600 \mathrm{ohm}$ and an average thickness of $2 \mathrm{~m}$. The third layer, whose base is indicated by the line with white dots, shows resistivity values of $10-70$ $\mathrm{ohm}$ and an average thickness of $6 \mathrm{~m}$. The fourth layer is characterized by resistivity values greater than $600 \mathrm{ohms}$. Therefore, the first and third layers are attributed to gravels, the second layer to silty sands, the fourth layer to the ACP Sandstone. Furthermore, the section of Figure 5(c) shows that the alluvial succession consisting of gravels-silty sands-gravels has a lenticular geometry and its thickness at the top of the ACP Sandstone is less than $2 \mathrm{~m}$ in proximity and under the arch 2.

The tectonic setting (Figure 3 and Figure 4) to the left of the Ofanto River shows bed attitude of the ACP Sandstone dipping $20^{\circ}-45^{\circ}$ towards SW and overturned beds dipping SW $70^{\circ}$, forming an inclined syncline with northeastern vergence, while to the right of the river the bed attitude is dipping $20^{\circ}-35^{\circ}$ towards SW forming gentle folds. The two structures to the left and right of the river are in contact by a SW-NE oriented normal fault. A second NNW-SSE oriented normal fault marks the contact between the ACP Sandstone and the succession consisting of AVR - AVR - - FYN (Figure 3 and Figure 4). 

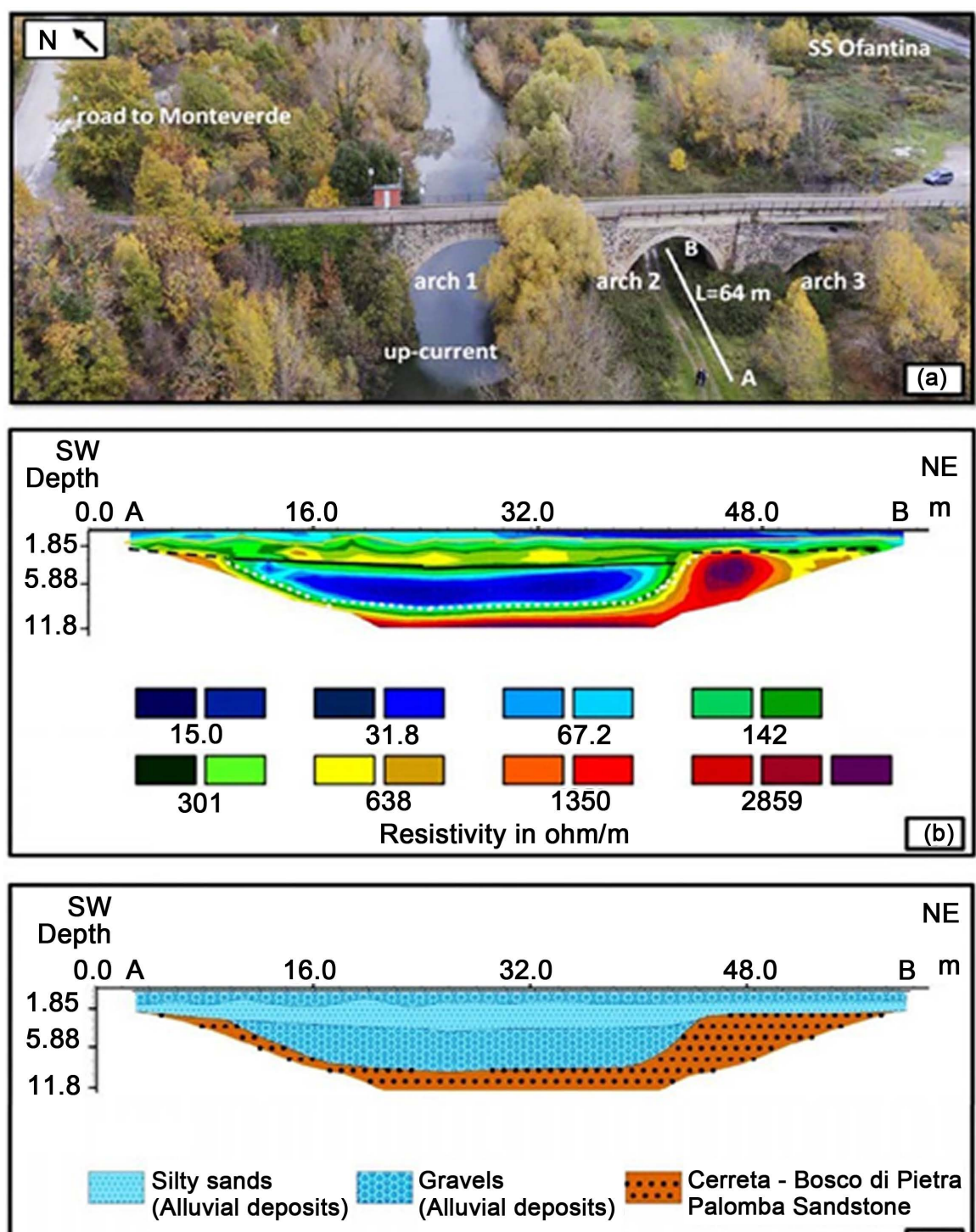

Figure 5. Location (a) and section (b) of the electrical resistivity tomography, and the related interpretation in lithological terms (c).

The section of the valley of the Ofanto River is about $50 \mathrm{~m}$ wide and the slopes, free of landslides, are inclined $26^{\circ}$ to the left and $10^{\circ}-20^{\circ}$ to the right of the river (Figure 4). In particular, it should be noted that the current incline $\left(20^{\circ}\right)$ of the right slope in the bridge area (Figure 4) decreased due the works of excavation carried out on the ACP Sandstone for the construction of the national road SS 401 dir and its connection with the bridge.

In addition, the hydrogeological and seismic hazards of the study area are very high (Ippolito \& Paganelli, 1984; http://www.difesa.suolo.regione.campania.it/ Vallario, 2001). The former hazard is due to: 1) sometimes impressing landslides, particularly in the very extensive areas characterized prevailingly by the Ruvo del Monte Synthem and subordinately the Varicolored Clays Formation; 2) widespread erosive phenomena caused by surface waters that are washed away and 
channeled along the streams flowing with high gradients in the hydrographic network of the Ofanto and Ufita rivers (Figure 1). The seismic hazard of Aquilonia, in whose territory the POB is included, and Monteverde (Figure 2) is classified in Zone 1, ie the most dangerous, characterized by acceleration index (ag) $>0.25$ with a probability of being exceeded equal to $10 \%$ in 50 years (http://www.lavoripubblici.regione.campania.it/). The earthquakes of July 23, 1930, and November 23, 1980, with a magnitude, respectively, of 6.67 and 6.81 (https://www.ingv.it/), affected the Campania and Basilicata Apennine, causing many deaths and damages to small towns and locally to some infrastructures. Due to the earthquake of July 23, 1930, Aquilonia was rebuilt in an area about 2 $\mathrm{km}$ southwest.

\section{Results}

\subsection{Historical Data from the Archives}

The research at the Municipality of Aquilonia and Engineer of Avellino, that is the public office that takes care of the maintenance of bridges and roads, revealed that there is no documentation regarding the bridge in 1900 .

Based on the indications of Massaro (1994), a dossier (Envelope 119) containing administrative documents of the Ministry of Public Works relating to the period 1856-1860 was examined at the State Archives of Napoli. In these documents, there is a concise reference to a project of the engineer Luigi Oberty (1790-1874), who joined the Royal Corps of Engineers of Bridges and Roads at the age of 19. In 1856 a request was made for the urgent repair of the POB. The work proposal was examined in 1858 and 1859, when the project of the Inspector of the Department engineer Luigi Oberty was presented to the Provincial Council of Principato Ultra. The Council deliberated that "without activating the width of the bridge, it is enough to make each prospectus by the palm 1 and 1/2; since it is a cart bridge the Inspector's proposal shall be accepted to suppress the upper part of the arches and instead, by repairing small arches, to study for a flooring, to make a ground fill and to put the crushed stones above it". This type of works did not substantially change the original architectonic and structural elements of the bridge, except the roadway.

\subsection{The Current State of the РOB}

The small dimensions of the width of the valley (about $50 \mathrm{~m}$ ) of the Ofanto River with slopes consisting of the ACP Sandstone and free of landslides are the ideal geomorphological conditions for building the bridge, which is of the masonry type (pons lapideus), in fair condition of conservation, without breakages and subsidence of the structures, and in operation with very little vehicular traffic. A masonry bridge consists of main and secondary structural elements and architectural elements (Galliazzo, 1995; Hughes \& Blackler, 1997; Gençer \& Turan, 2017). To highlight the current state of the architectural and structural elements (ASEs) of the POB and therefore to recognize which are original and which of 
them were restored, modified, reconstructed, and, eventually, added for consolidation, we performed the material survey of the bridge (Figure 6 and Figure 7). This survey showed that the main structural elements include the abutments, three arches ( 1 on the river channel, 2, and 3 in Figure 6 and Figure 7) with semicircular curvature to the intrados profile (round arch), already recognized by Lenormant (1883) and De Lorenzo (1906), the spandrel walls, the piers, the foundations, and the buttresses. The secondary structural elements consist of the cutwaters and the relieving arches, and the architectonic elements include the roadway and the parapet walls.

Abutments. These lie on the ACP Sandstone. The northwestern abutment is original, made up of masonry in small apparatus with alluvial pebbles, while the southeastern one was modified by the works carried out to allow the connection of the national road SS 401 dir to the bridge. The termination of the northwestern abutment is connected, in addition to the road to Monteverde, to the
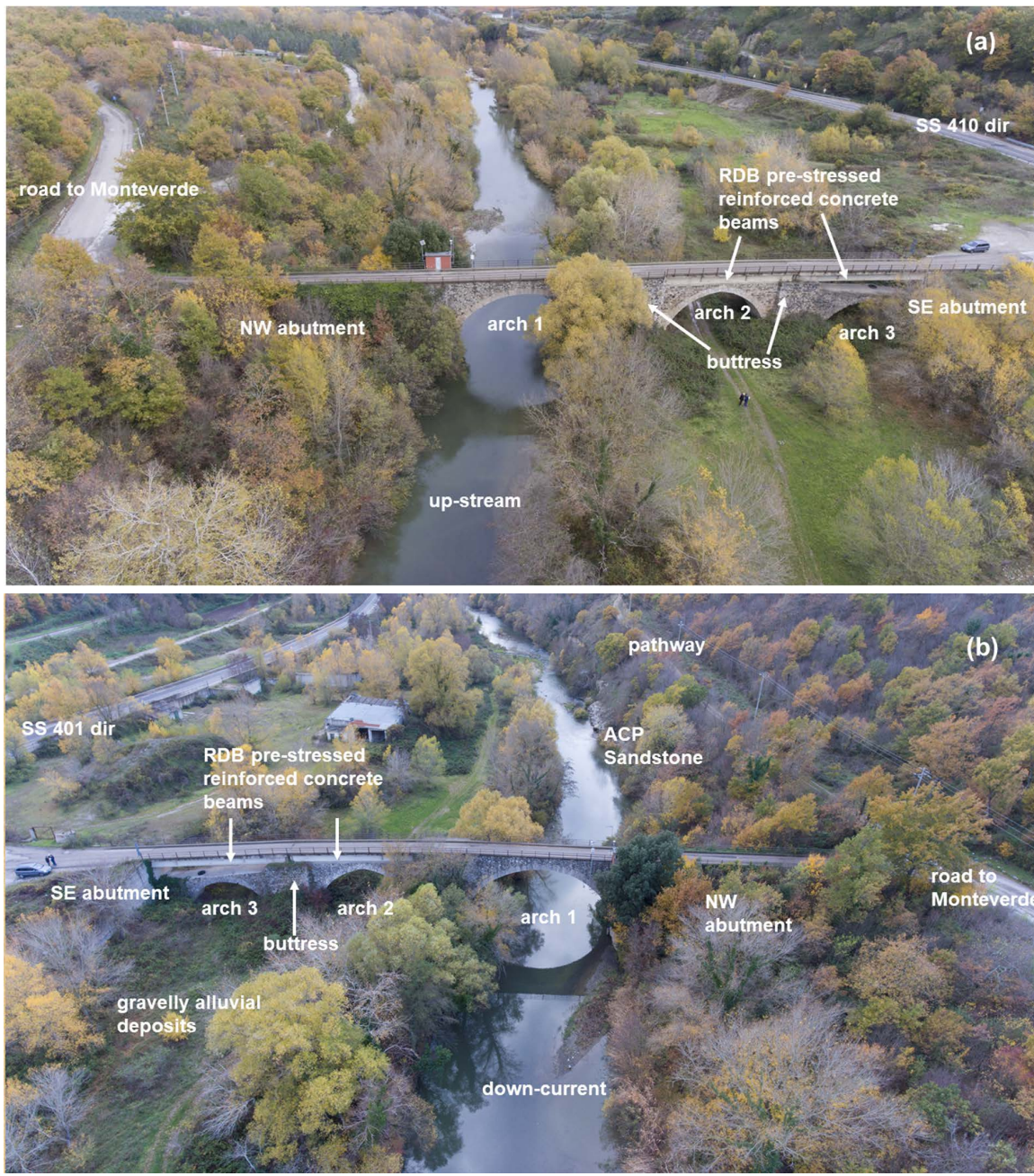

Figure 6. Current state of the façade of the POB as seen through the drone up-stream (southwest) in (a) and down-stream (northeast) in (b). The abutments, the arches 2 and 3 and the cutwaters are covered by weed and climbing vegetation. The pathway in (b) coincides with the layout of the old Appian Way. 


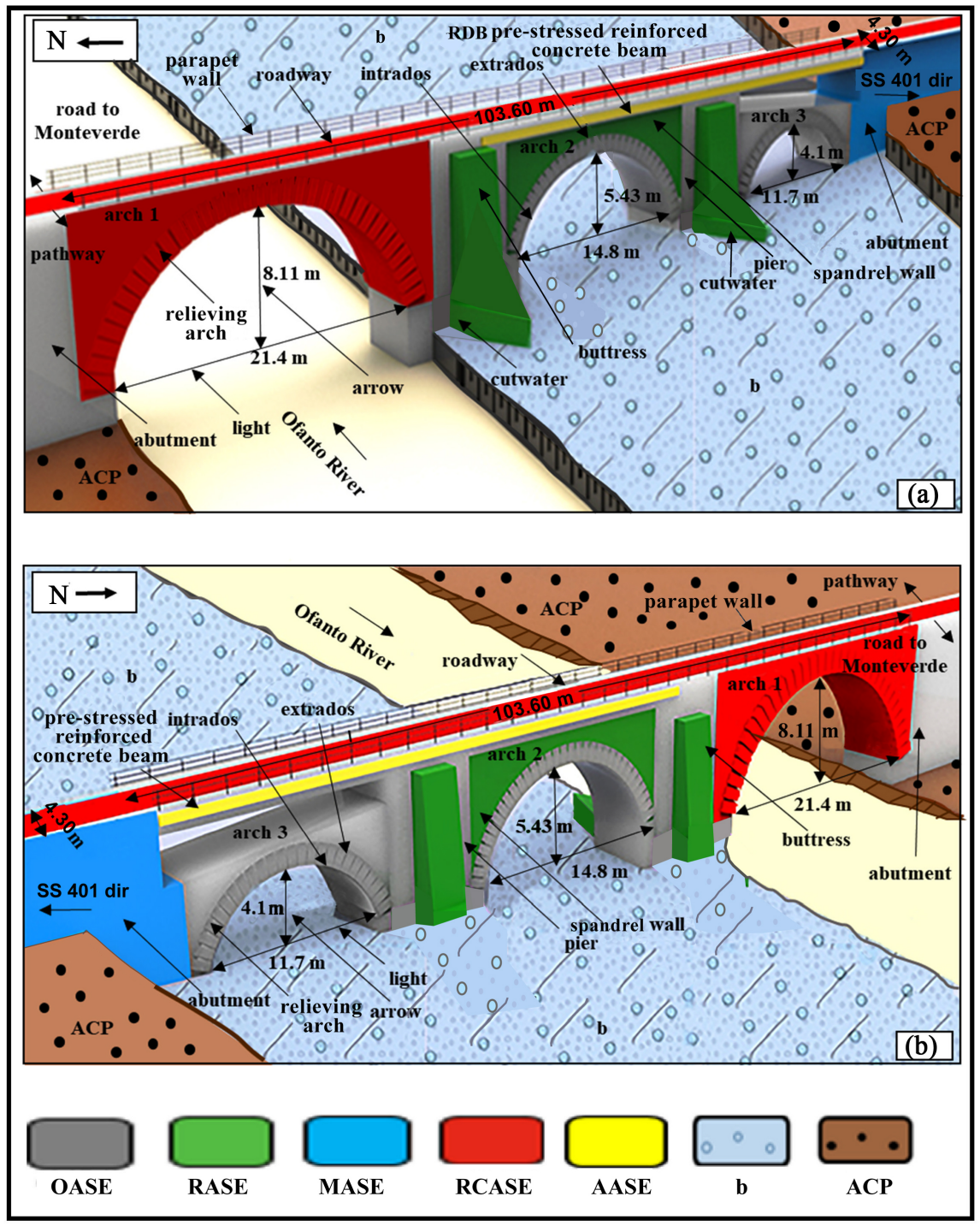

Figure 7. The 3D model illustrates the current state of the POB through the material survey of its architectonic and structural elements (ASEs), seen up-stream in (a) and down-stream in (b). OASEs (original: the northwestern abutment, the arches 2 and 3 , their relieving arches, the piers, the spandrel wall of the arch 3, the foundations); RASEs (restored: the spandrel walls of the arch 2, the buttresses, the cutwaters); MASEs (modified: the southeastern abutment); RCASEs (reconstructed: the arch 1, the roadway, and the parapet walls); AASEs (added: RDB pre-stressed reinforced concrete beams); (b) alluvial deposits; ACP, Cerreta-Bosco di Pietra Palomba Sandstone.

pathway with a straight trend (Figure 6(b)) that follows the layout of the old Appian Way (Chiocchini et al., 2016). There is no trace of the fourth arch which, according to Aveta et al. (2012), was covered due to the reconstruction of the road to Monteverde.

Arch 1. It was reconstructed through the works probably carried out because of the earthquakes of July 23, 1930 and November 23, 1980. The light is $21.4 \mathrm{~m}$ long and the arrow $8.11 \mathrm{~m}$. Arrow/light ratio $=0.38$.

Arch 2. It is original. The light is $14.8 \mathrm{~m}$ long and the arrow $5.43 \mathrm{~m}$. Ar- 
row/light ratio $=0.37$.

Arch 3. It is original. The light is $11.7 \mathrm{~m}$ long and the arrow $4.1 \mathrm{~m}$. Arrow/ light ratio $=0.35$.

The masonry of the face of arches 2 and 3 is in small apparatus including alluvial pebbles of marly and siliceous limestone with mainly blade shapes (Figure 8), some irregular ashlars of phytoclastic travertine with larger dimensions in the upper part of the arches and rare fragments of bricks. The analysis of the masonry texture and the construction technique of the face of arches 2 and 3, which are an important basis for their dating, shows that the pebbles, the phytoclastic travertine ashlars and the rare fragments of bricks are arranged lying in homogeneous courses with the tiled structure according to fairly regular beds (Figure 8), exactly as Vitruvio describes the construction technique in small apparatus of the opus incertum (De Architectura II, VIII ${ }^{1}$ ).

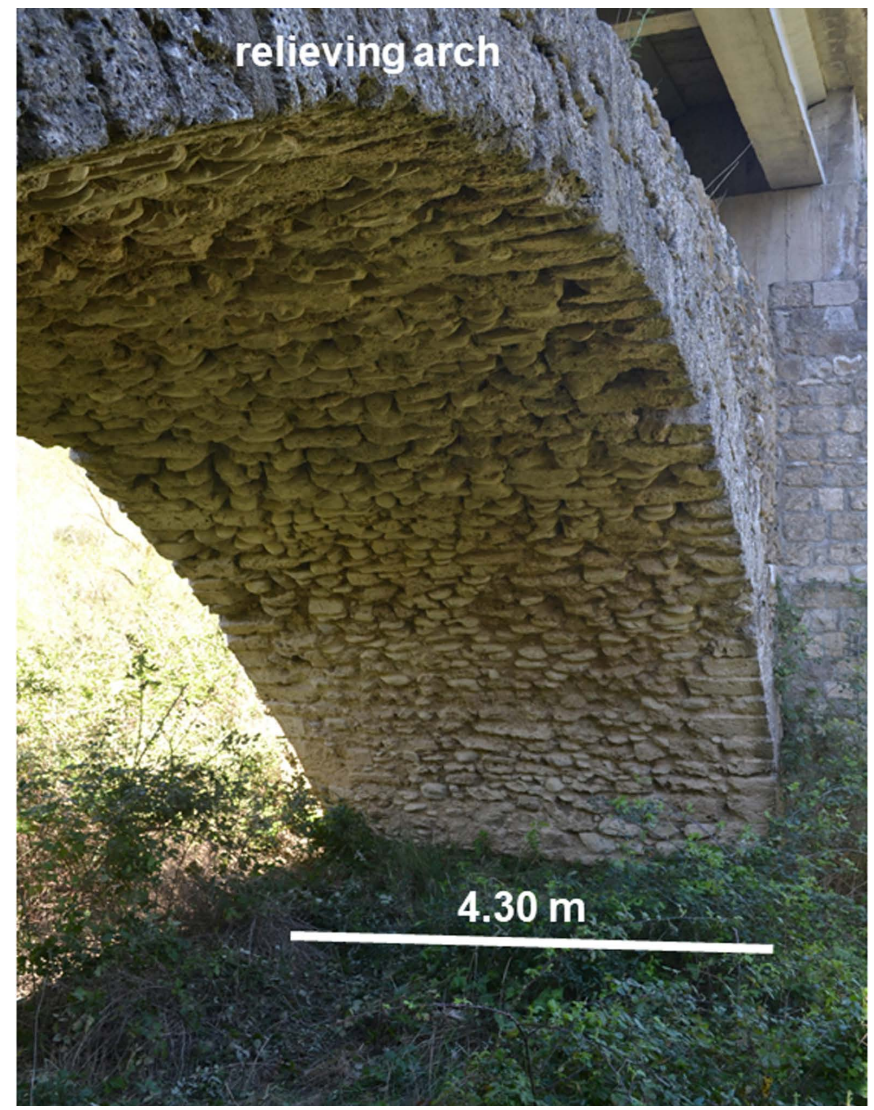

Figure 8. Face of the arch 3, $4.30 \mathrm{~m}$ wide, showing the opus incertum, consisting of marly and siliceous limestone pebbles with a blade shape and tiled structure, and the relieving arch with the squared ashlars of phytoclastic travertine.

${ }^{1}$ II, VIII. "There are two styles of walls: opus reticulatum, used today by everybody and the one called opus incertum in use in ancient times. The former is more elegant, but prone to cracking because it has connections in every direction. On the other hand, in the opus incertum the stones lie in courses on top of each other with tiled structure and have a less elegant but more solid structure than the opus reticulatum. In both cases, however, it should be built with very small stones so that the mortar-impregnated walls have longer durability." 
Spandrel walls. These are triangular parts of wall. Those of arch 2 were restored, while those of arch 3 are original in small apparatus with pebbles and ashlars of phytoclastic travertine.

Piers. They have a rectangular base, are original and built by the opus quadratum, including squared ashlars (average size of length $0.65 \mathrm{~m}$, width $0.35 \mathrm{~m}$, thickness $0.25 \mathrm{~m}$ ) of the phytoclastic travertine (Figure 9). The piers have a thickness, corresponding to the long side of the base, between $4.35 \mathrm{~m}$ (arches 1 and 2$)$ and $4.28 \mathrm{~m}(\operatorname{arch} 3)$.

Buttresses. These are reinforcing piers with a rectangular base. At present (Figure 6 and Figure 9) there are 6 restored on the sides of the arches both up-current and down-current, built by the opus quadratum, consisting of squared ashlars (average dimensions of length $0.50 \mathrm{~m}$, width $0.24 \mathrm{~m}$, thickness $0.20 \mathrm{~m}$ ) of ACP Sandstones and phytoclastic travertine.

Foundations. Based on the geological survey (Figure 3 and Figure 4) and the electrical resistivity tomography (Figure 5), which highlight the presence of the ACP Sandstone under the alluvial deposits with a thickness of less than $2 \mathrm{~m}$ (Figure $5(\mathrm{c})$ ), it is reasonable to assume that there are four original foundations of direct type resting on the ACP Sandstone.

Relieving arches. The four relieving arches of the arches 2 and 3 are original and consist of masonry in small apparatus with squared ashlars of phytoclastic travertine (Figure 8).

Cutwaters. These two defenses, covered by weed and climbing vegetation (Figure 6(a)), have a pyramidal shape on a triangular base (Figure 7(a)) and are

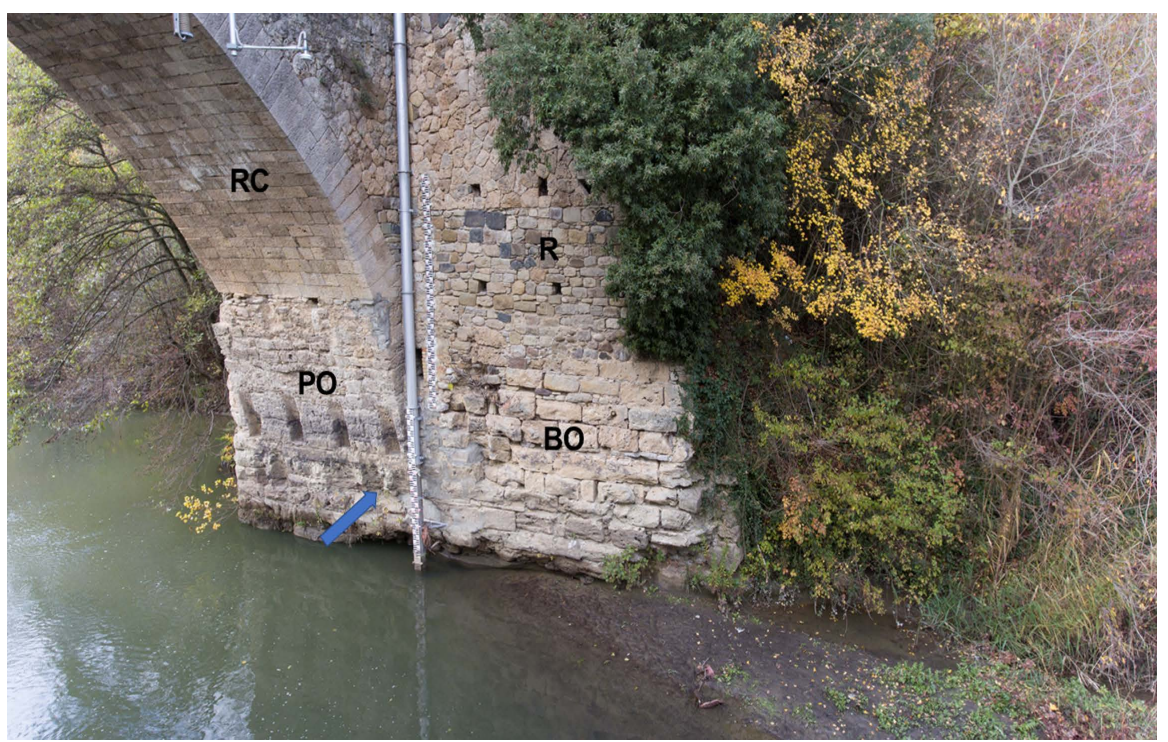

Figure 9. The photo shows, on the left bank of the Ofanto River, the reconstructed arch 1 (RC), the original structures of the pier (PO), from which the sample PO 11 of mortar highlighted by the arrow was collected, and, on the right, the base of the buttress (BO). The middle upper part of the buttress is restored (R) mainly with squared ashlars of ACP Sandstones and some pebbles of dark gray siliceous limestone. The vertical tube is part of the hydrometric device. 
restored with squared ashlars of phytoclastic travertine and a few ashlars of marly limestones. The cutwater between arches 1 and 2 is integral, while the cutwater between arches 2 and 3 has a lower height because the middle upper part is demolished.

Roadway. The original one, $103.60 \mathrm{~m}$ long and $4.30 \mathrm{~m}$ wide, was also rebuilt due to the works for the construction of the national road SS 401 dir.

Parapet walls. The current ones, which also include two sidewalks with a total width of $0.48 \mathrm{~m}$, are reconstructed. It can be assumed that the original parapets had a width of $0.45 \mathrm{~m}$ with an outward projection, like in most Roman bridges (O’Connor, 1993; Galliazzo, 1995).

Ratio pier thickness/arch light. According to Galliazzo (1995) in general this ratio in modern masonry bridges is considered "good" if it is about $1 / 5$ of the light. The ratio values are about $1 / 3.4$ for the arch 2 and $1 / 2.7$ for the arch 3 of the POB, like to the rather low values between $2 / 3$ (or 1/2) and $1 / 4$ of most of the Roman masonry bridges. These values indicate that the piers guarantee complete safety for the support of the arches.

The most significant and conspicuous modifications of the bridge involved the following elements: 1) reconstruction of the arch 1;2) insertion of four RDB pre-stressed concrete beams (Figure 6), of which two, $20.5 \mathrm{~m}$ long, are raised $1.5-2 \mathrm{~m}$ with respect to the arch 3, while two, $18.4 \mathrm{~m}$ long, rest on the arch 2; these elements are referred to as added ASEs (AASEs); 3 ) modification of the southeastern abutment.

Thus, the bridge ASEs include two groups illustrated in the 3D model of the bridge (Figure 7). The former group consists of 18 original ASEs built using the techniques of opus quadratum and opus incertum (OASEs: the northwestern abutment, the arches 2 and 3, four relieving arches, three piers, four spandrel walls of the arch 3, four foundations). It should be noted that, based on the very numerous macroscopic observations, the mortar of OASEs shows the following uniform features: it is very hard; medium-fine grained; of very light gray $\mathrm{N} 8$ color; the field tests with $10 \%$ hydrochloric acid suggest that it is always very rich in calcite.

The latter group consists of 12 restored ASEs (RASEs: four spandrel walls of the arch 2, six buttresses, two cutwaters), 1 modified ASE (MASE: the southeastern abutment), 4 reconstructed ASEs (RCASEs: the arch 1, the roadway, and two parapet walls), and 4 ASEs added for consolidation (AASE: four RDB pre-stressed reinforced concrete beams). These restorations, modifications, reconstructions, and additions are due to interventions carried out between the early 1900s and today, largely for the construction of the national road SS 401 dir and its connection to the bridge, and as a consequence of the earthquakes of July 23, 1930 and November 23, 1980. Furthermore, bearing in mind that the average width of the distance between the wheels of the Roman wagons was about $1.30 \mathrm{~m}$ (Galliazzo, 1995), the original roadway, $4.30 \mathrm{~m}$ wide including the sidewalks $(3.40+0.45 \times 2)$, could allow the transit of wagons in two ways. Table 1 summarizes the data that characterize the bridge. 
Table 1. Characteristic data of the Pietra dell'Oglio bridge.

\begin{tabular}{|c|c|}
\hline \multirow{5}{*}{ Location } & Municipality of Aquilonia \\
\hline & Province of Avellino \\
\hline & Campania Region \\
\hline & Map of the Military Geographic Institute: Sheet 187 Melfi-Section IV \\
\hline & NO at scale $1: 25,000$ \\
\hline Type & Masonry bridge on the Ofanto River \\
\hline Current use & $\begin{array}{l}\text { Road bridge that originally connected Monteverde only to its railway } \\
\text { station and later also to the national road SS } 401 \mathrm{dir}\end{array}$ \\
\hline Age and function & $\begin{array}{l}\text { II - I century BC. It is the Pons Aufidi of the Tabula Peutingeriana and is } \\
\text { referred to the layout of the old Appian Way between Mirabella Eclano } \\
\text { (Aeclanum) and Venosa (Venusia). }\end{array}$ \\
\hline $\begin{array}{l}\text { Conservation } \\
\text { status }\end{array}$ & Fair \\
\hline & There is no news about recent works at the Municipality of \\
\hline Historical news & $\begin{array}{l}\text { Aquilonia and Engineer of Avellino. At the State Archive of Napoli } \\
\text { there is the documentation relating to some works on the bridge } \\
\text { decided by the Provincial Council of the Principato Ultra in 1858-1859. } \\
\text { These works do not have altered the original structure of the bridge. }\end{array}$ \\
\hline $\begin{array}{l}\text { Materials used for } \\
\text { the construction }\end{array}$ & $\begin{array}{l}\text { Pebbles, phytoclastic travertine, Cerreta-Bosco di Pietra Palomba } \\
\text { Sandstone (ACP), fragments of bricks. The mortar includes aggregates } \\
\text { of quartz, K-feldspar, sandstone fragments and binder consisting of mi- } \\
\text { cro-spar, spar, and micrite. }\end{array}$ \\
\hline
\end{tabular}

\section{Abutments}

The northwestern abutment is original and consists of masonry with pebbles. The southeastern one was modified by the works to connect the bridge to the national road SS $401 \mathrm{dir}$.

\section{Arches}

The bridge consists of three roud arches. The arch 1 on the Ofanto River is rebuilt. The arches 2 and 3 are original and with the face built by the technique of the opus incertum. The dimensions of the light and arrow decrease from the arch 1 to the arch 3.

\section{Spandrel walls}

Those of the arch 2 are restored, those of the arch 3 are original. The masonry is built with pebbles and squared ashlars of phytoclastic travertine.

\section{Piers}

They have a rectangular base, are original and built with the technique of

Architectural and structural elements (ASEs) the opus quadratum.

\section{Buttresses}

They have a rectangular base, are restored and built with the techniques of opus quadratum.

\section{Foundations}

They are original of direct type resting on the Cerreta-Bosco di Pietra Palomba Sandstone (ACP).

\section{Relieving arches}

Those of the arches 2 and 3 are original and consist of squared ashlars of phytoclastic travertine.

\section{Cutwaters}

They have a pyramidal shape on a triangular base and are restored.

\section{Roadway}

The original one is $103.60 \mathrm{~m}$ long and $4.30 \mathrm{~m}$ wide and is rebuilt.

\section{Parapet walls}

The current ones, which also include two sidewalks with an overall width of $0.48 \mathrm{~m}$, are rebuilt. The original ones were $0.45 \mathrm{~m}$ wide.

\section{Ratio pier thickness/arch light}

The values of the ratio are $1 / 3.4$ for the $\operatorname{arch} 2$ and $1 / 2.7$ for the $\operatorname{arch} 3$. 


Original (OASEs)
The northwestern abutment, the arches 2 and 3, the relieving arches and
the piers of the arches 2 and 3, the spandrel wall of the arch 3, the direct
foundations.
Restored ( $R A S E s)$
The spandrel wall of the arch 2, the buttresses and the cutwaters.
Modified (MASEs)
The southeastern abutment.
Reconstructed ( $R C A S E s)$
The arch 1, the roadway, and the parapet walls.
Tdded ( $A$ ASEs)
4 RDB pre-stressed reinforced concrete beams.
The arch 1 on the Ofanto River was rebuilt and four RDB pre-stressed
reinforced concrete beams were inserted between the southeastern
abutment and the arches 2 and 3 probably as a result of the earthquakes
of July 23,1930 and November $23,1980$.
The southeastern abutment was modified to connect the national
road SS 401 dir to the bridge.

\subsection{Raw Materials Used for the Construction of the Bridge}

\subsubsection{Sampling}

For the construction of the bridge OASEs, TRV phytoclastic travertine, ACP Sandstone, "b" alluvial pebbles, rare fragments of bricks, and mortar were used. The first three types of materials were also used for the restoration and reconstruction of some architectural and structural elements. Therefore, in order to define the mineralogical, petrographic, density and strength characteristics of the materials used for the construction of the OASEs, the following 15 samples, appointed by the acronyms PO and POS, were collected (Table 2).

- Four samples of phytoclastic travertine from the ashlars of the arch 2 (PO 1) (Figure 10(a)) and arch 3 (PO 2) (Figure 10(b)) and for comparison from the outcrops of TRV in the nearby area between Foggiano and the Ofanto River (PO 3 and PO 4) (Figure 3) to be examined by petrographic analysis. In this area the repeated anthropic interventions and the modelling processes produced, for over 2000 years, substantial changes of the slightly steep slopes, where it is not possible to recognize evident archaeological traces of excavation on the surface for the mining of travertine.

- Six cores from the outcrop of the ACP Sandstone on the right side of the Ofanto River, of which 2 (PO 5 and PO 6) for petrographic analysis and 4 (POS 1, POS 2, POS 3, POS 4) (Figure 3) to determine its strength.

- Two pebbles (PO 7, PO 8) of "b" alluvial deposits (Figure 3).

- Taking into account that the macroscopic characteristics of the mortar are uniform, three samples of this material from the arch 2 (PO 9) (Figure 10(a)), arch 3 (PO 10) (Figure 10(b)) and the pier of arch 1 on the left bank of the Ofanto River (PO 11) (Figure 9) for mineralogical and petrographic analysis and density test. 
Table 2. Distribution of samples (PO 3, PO 4, PO 5, PO 6, PO 7, PO 8) and cores (POS 1, POS 2, POS 3, POS 4) collected from the outcrops and samples from the arch 2 (PO 1 and PO 9), arch 3 (PO 2 and PO 10), and the pier of arch 1 (PO 11). b, alluvial deposits; TRV, polymictic gravels and phytoclastic travertine; ACP, Cerreta-Bosco di Pietra Palomba Sandstone. Sampling location is shown in Figure 3 (PO 3 - 8; POS 1 - 4), Figure 9 (PO 11), and Figure 10 (PO 1, 2, 9, 10).

\begin{tabular}{|c|c|c|c|c|c|}
\hline Materials & Formation & Outcrop & $\operatorname{Arch} 2$ & Arch 3 & Pier of $\operatorname{arch} 1$ \\
\hline Pebbles & $\mathrm{b}$ & $\mathrm{PO} 7, \mathrm{PO} 8$ & & & \\
\hline $\begin{array}{l}\text { Phytoclastic } \\
\text { travertine }\end{array}$ & TRV & $\mathrm{PO} 3, \mathrm{PO} 4$ & PO 1 & $\mathrm{PO} 2$ & \\
\hline Sandstone & $\mathrm{ACP}$ & $\begin{array}{c}\text { PO 5, PO 6, POS 1, POS } 2, \\
\text { POS } 3, \text { POS } 4\end{array}$ & & & \\
\hline Mortar & & & PO 9 & PO 10 & PO 11 \\
\hline
\end{tabular}

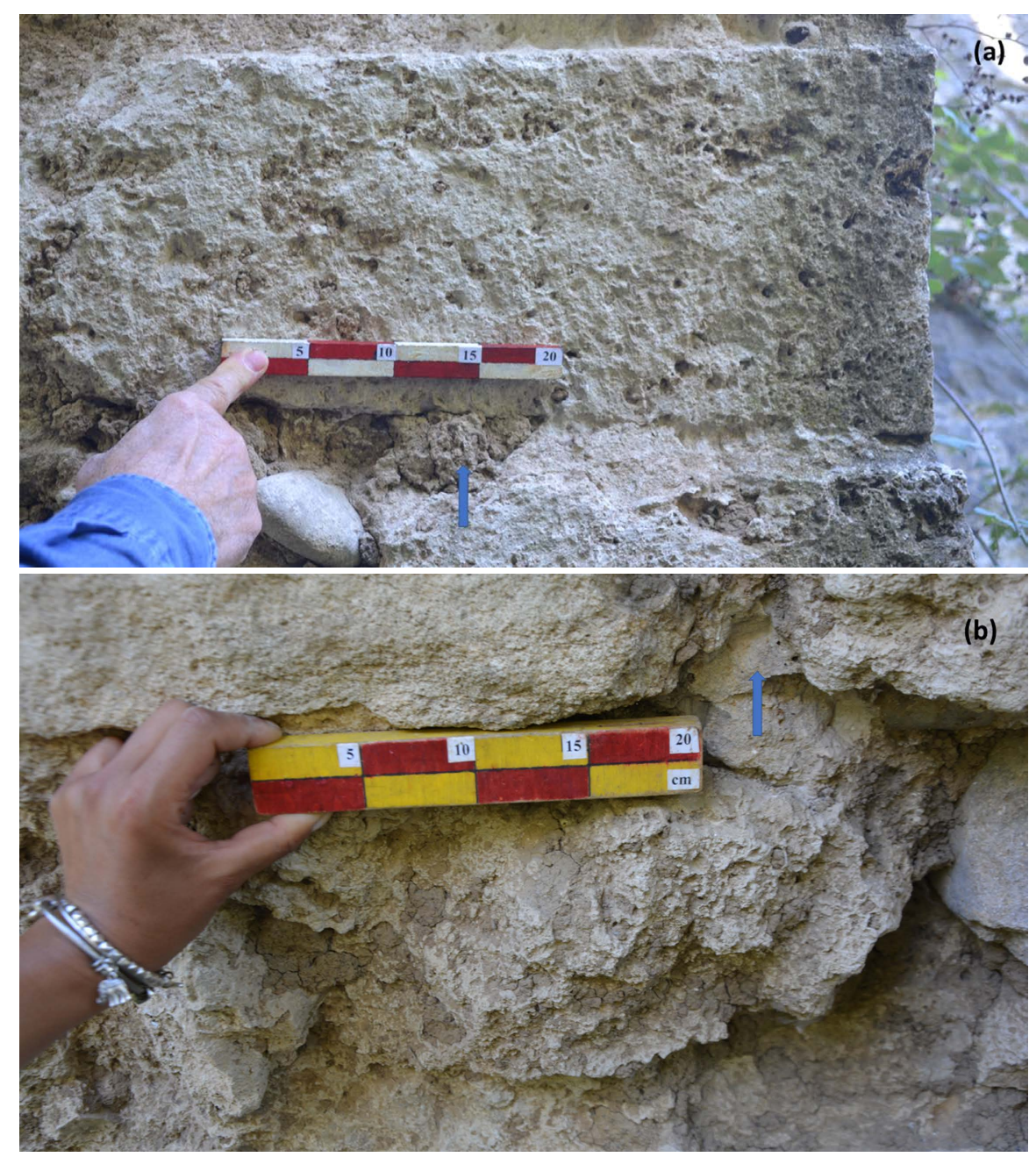

Figure 10. The phytoclastic travertine ashlars, showing the characteristic pores, and the mortar of arch 2 (a) and arch 3 (b), from which the samples PO 1 and PO 9, PO 2 and PO 10 were collected, respectively. The mortar is highlighted by arrow.

\subsubsection{Petrographic Analysis of TRV Phytoclastic Travertine, ACP Sandstone and "b" Alluvial Deposits}

Samples PO 1, PO 2, PO 3, PO 4. The most common petrographic components 
of TRV are micro-spar (calcite crystals between 5 and $15 \mathrm{~mm}$ ) and micrite (calcite crystals with diameter $<5 \mathrm{~mm}$ ) with minor spar or pseudo-spar (calcite crystals $>15 \mathrm{~mm}$ ). Micrite and micro-spar frequently form laminated, peloidal, aphanitic, and dendritic fabric (Figure 11 and Figure 12). The composition and

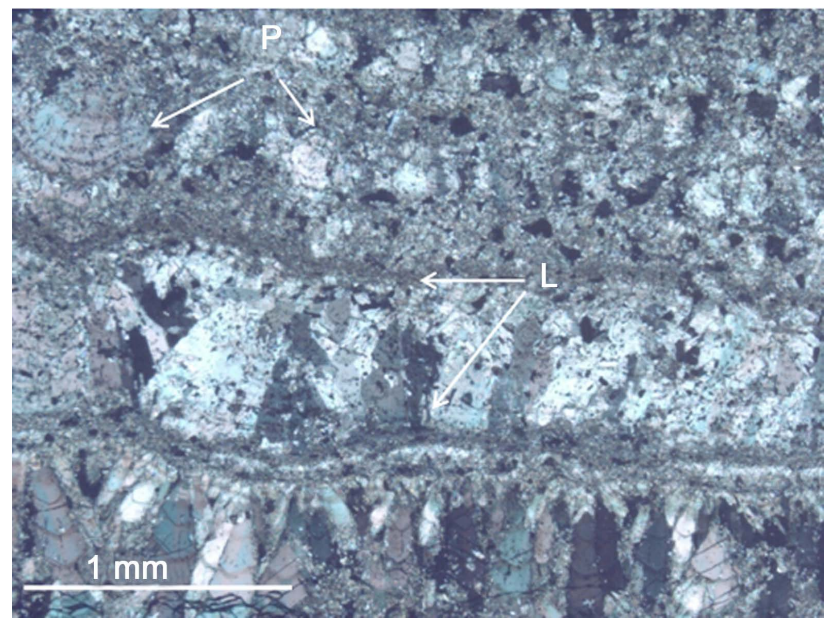

Figure 11. Photomicrograph of the sample PO 1 of phytoclastic travertine collected from the ashlar of the arch 2 observed under crossed nicols. The arrows indicate the laminar $(\mathrm{L})$ and peloidal (P) fabric.

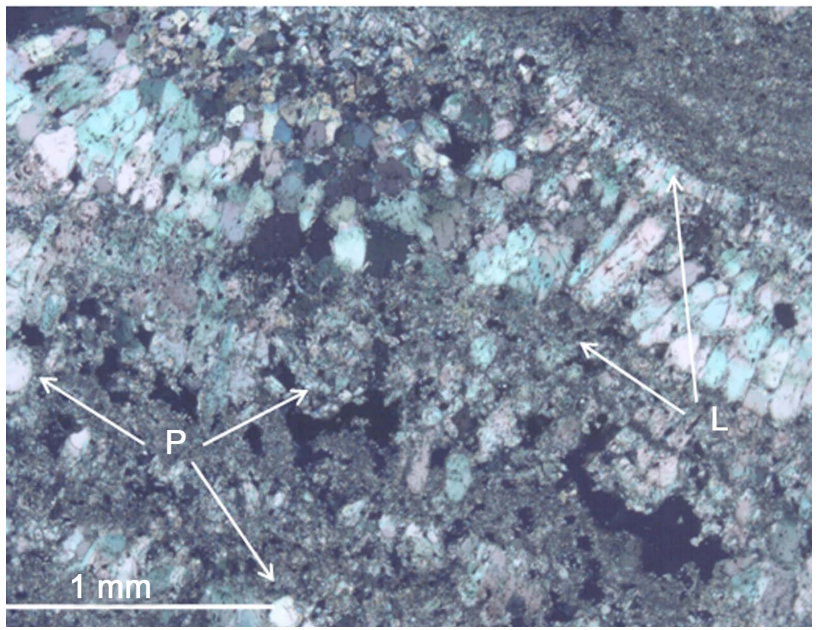

Figure 12. Photomicrograph of the sample PO 3 of phytoclastic travertine collected from the area between Foggiano and the Ofanto River observed under crossed nicols. The arrows indicate the laminar (L) and peloidal (P) fabric.

fabric suggest that the examined samples consist of the same type of TRV phytoclastic travertine or calcareous tufa (D'Argenio \& Ferreri, 1988; D'Argenio et al., 2013; Capezzuoli \& Gandin, 2004; Gandin \& Capezzuoli, 2008; Gandin, 2013; Capezzuoli et al., 2014; Imbriale, 2014).

Samples PO 5, PO 6. The petrographic analysis of the ACP Sandstone shows that the texture includes abundant coarse $(0.73-1.10 \mathrm{~mm})$ sub-angular and an- 
gular grains, generally fractured, of monocrystalline and polycrystalline quartz, $\mathrm{K}$-feldspar (orthoclase and microcline) and plagioclase, and less frequent grains of rock fragments (crystalline rocks and limestone) bounded by calcite cement (Figure 13). In addition, there are also microfossils including large foraminifera as Lepidocycline and Miogypsine (Figure 14), probably resedimented (see the

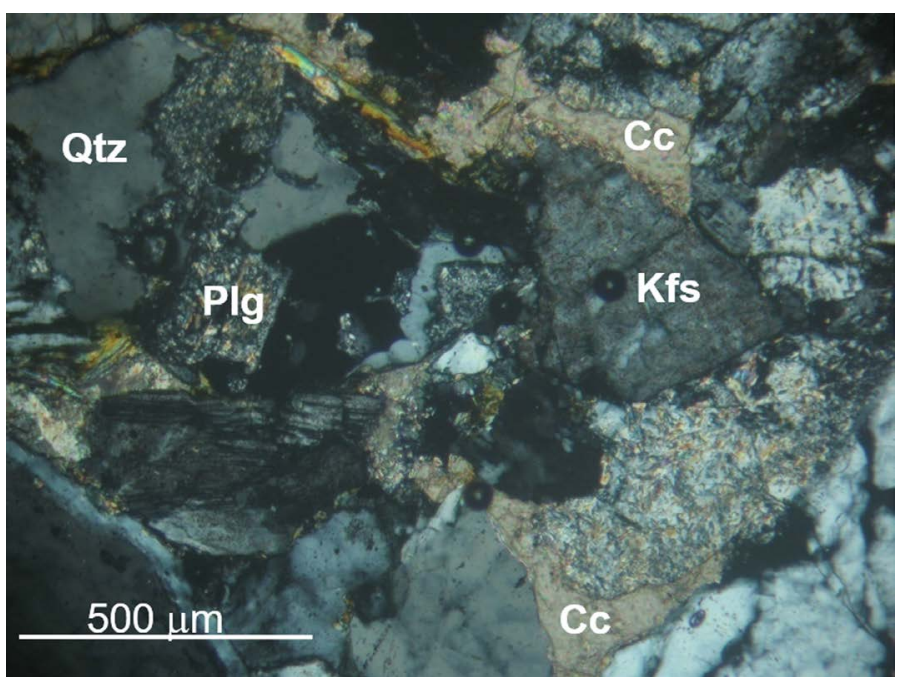

Figure 13. Photomicrograph of the sample PO 5 of arkose observed under crossed nicols. The texture is made up of quartz (Qtz), $\mathrm{K}$-feldspar (Kfs), and plagioclase (Plg) bounded by calcite cement (Cc). The plagioclase crystals are almost totally transformed in a fine aggregate of white mica and calcite.

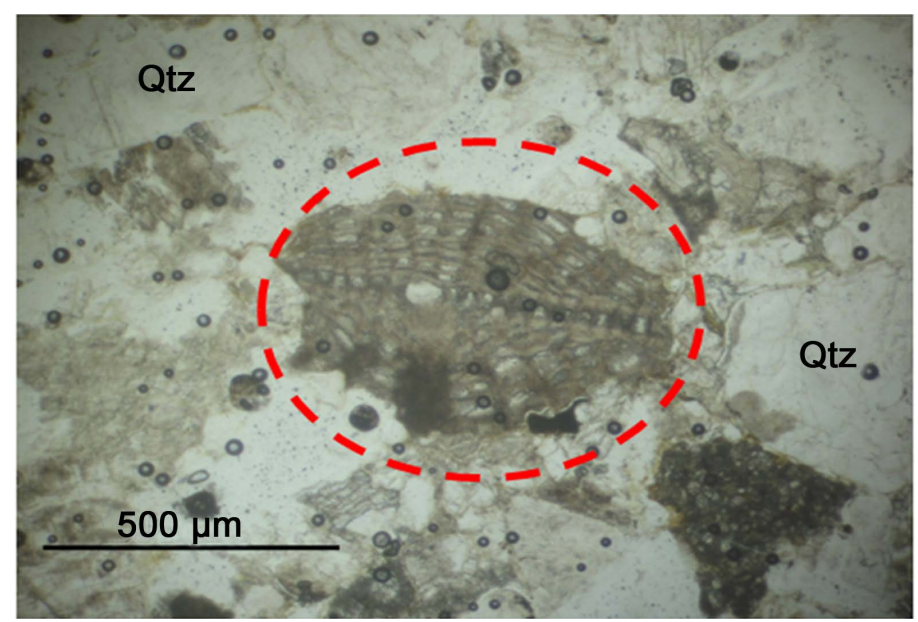

Figure 14. Photomicrograph of the sample PO 5 of arkose observed under crossed nicols. The red circle highlights a Lepidocyclina sp. Qtz, quartz.

items Resedimentation and Turbidity currents of American Geological Institute (2005)), as occurs in the turbidite formations of different ages across the whole Apennine chain (Consiglio Nazionale delle Ricerche, 1990; APAT, 2005). Therefore, the ACP Sandstone has a quartz-feldspar composition of arkose type 
(Schiattarella et al., in press).

Samples $P O$ 7, $P O$ 8. These pebble samples from the "b" alluvial deposits are marly and siliceous mudstones rich in planktonic foraminifera, radiolarians, generally turned in calcite, and sponge spicules.

\subsubsection{Mineralogical and Petrographic Analysis of Mortar}

Samples $P O$ 9, $P O$ 10, $P O$ 11. The mineralogical analysis by $\mathrm{X}$ ray indicates that the composition of the mortar is almost identical, including about $24 \%$ of quartz, $16 \%$ of K-feldspar, and $60 \%$ of calcite, as illustrated by the diffractogram of the sample PO 9 in Figure 15. The modal percentage analysis in thin section (Table 3 ) shows that the mortar samples contain similar quantities of medium-fine aggregates $(0.20-0.125 \mathrm{~mm}$ ), composed of quartz (arithmetic average 17.5\%), K-feldspar (arithmetic average 11.6\%), sandstone fragments (arithmetic average $10.2 \%$ ), and binder including micro-spar and spar (arithmetic average 36.8\%), and micrite (arithmetic average 23.8\%) (Figure 16). Therefore, the mortar consists of $60.7 \%$ of binder and $39.3 \%$ of aggregates and the binder/aggregate ratio shows almost identical values (arithmetic average 1.5\%) (Table 3). In addition, the SEM analysis highlights the presence of a particular form of calcite consisting of a fragment of microfossil (Figure 17).

Table 3. Modal percentage analysis of the aggregates and binder of the mortar samples. B/A, binder/aggregate ratio. Aggregates: Qtz, quartz; Kfs, K-feldspar; Ss, sandstone fragments. Binder: Cs, micro-spar and spar; $\mathrm{Cm}$, micrite.

\begin{tabular}{ccccccccc}
\hline Sample & B/A & Qtz & Kfs & Ss & Cs & Cm & $\begin{array}{c}\text { Total } \\
\text { aggregate }\end{array}$ & $\begin{array}{c}\text { Total } \\
\text { binder }\end{array}$ \\
\hline PO 9 & 1.5 & 18.2 & 11.1 & 10.2 & 37.4 & 23.1 & 39.5 & 60.5 \\
PO 10 & 1.6 & 17.1 & 11.4 & 10.3 & 36.8 & 24.4 & 38.8 & 61.2 \\
PO 11 & 1.5 & 17.2 & 12.3 & 10.1 & 36.3 & 24.1 & 39.6 & 60.4 \\
$\begin{array}{c}\text { Arithmetic } \\
\text { average }\end{array}$ & 1.5 & 17.5 & 11.6 & 10.2 & 36.8 & 23.8 & 39.3 & 60.7 \\
$\begin{array}{c}\text { Standard } \\
\text { deviation }\end{array}$ & 0.05 & 0.50 & 0.51 & 0.08 & 0.45 & 0.55 & 0.35 & 0.35 \\
\hline
\end{tabular}

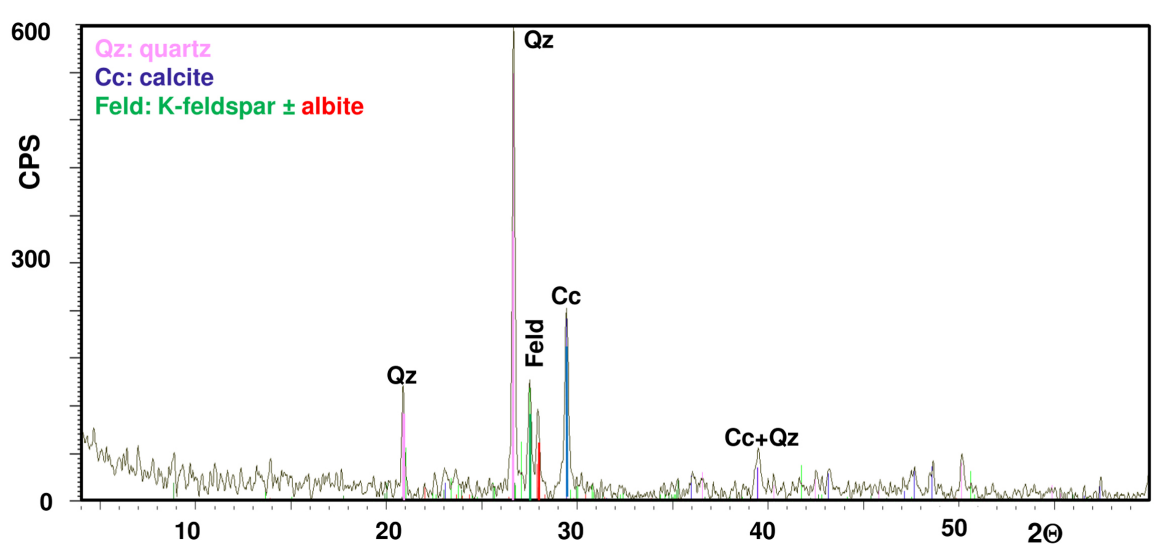

Figure 15. Diffractogram of the sample PO 9 of mortar. 

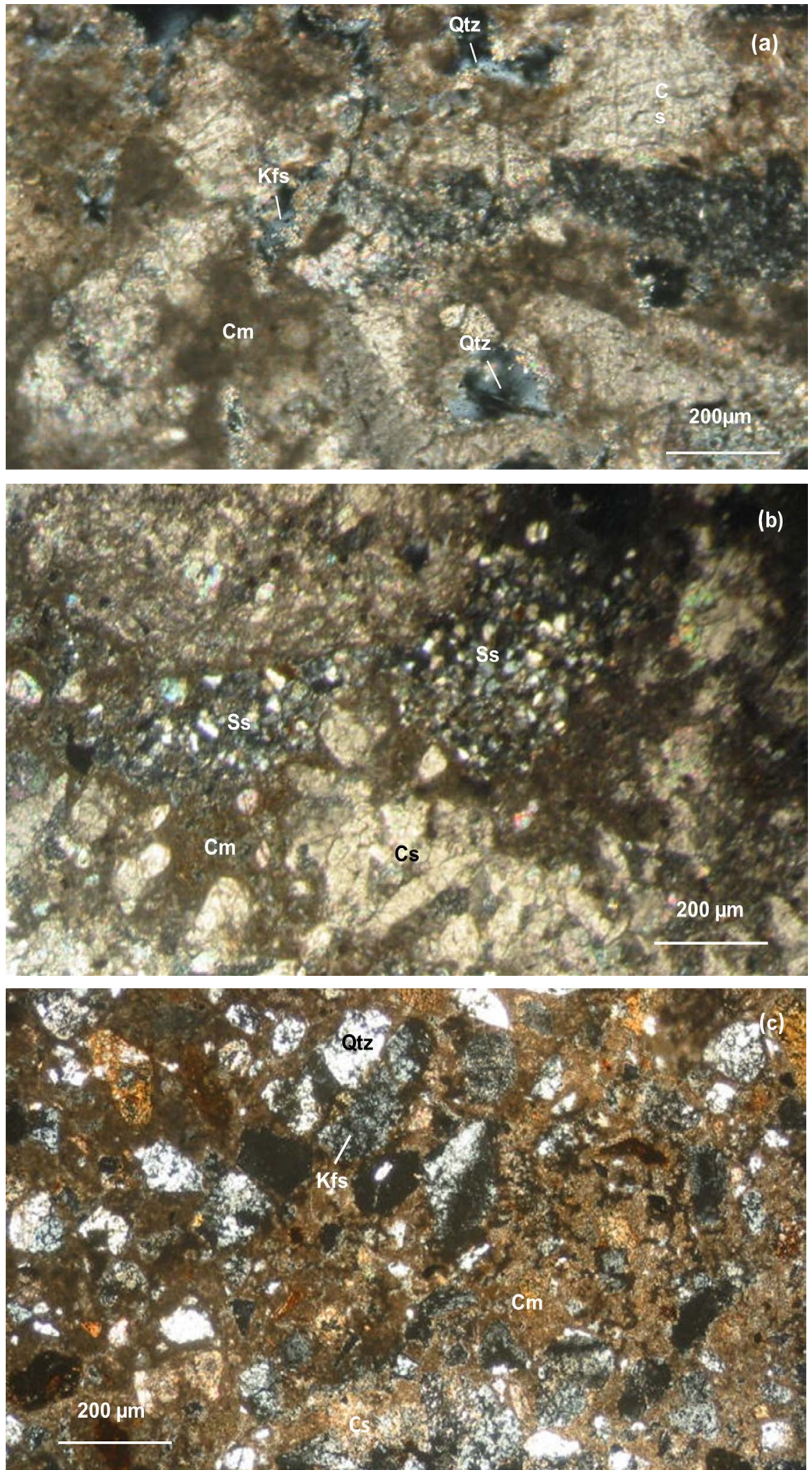

Figure 16. Photomicrographs of the samples PO 9 (a), PO 10 (b), and PO 11 (c) of mortar observed under crossed nicols. The texture includes aggregates of quartz (Qtz), $\mathrm{K}$-feldspar (Kfs), sandstone fragments (Ss), and binder consisting of spar and micro-spar (Cs), and micrite $(\mathrm{Cm})$. 


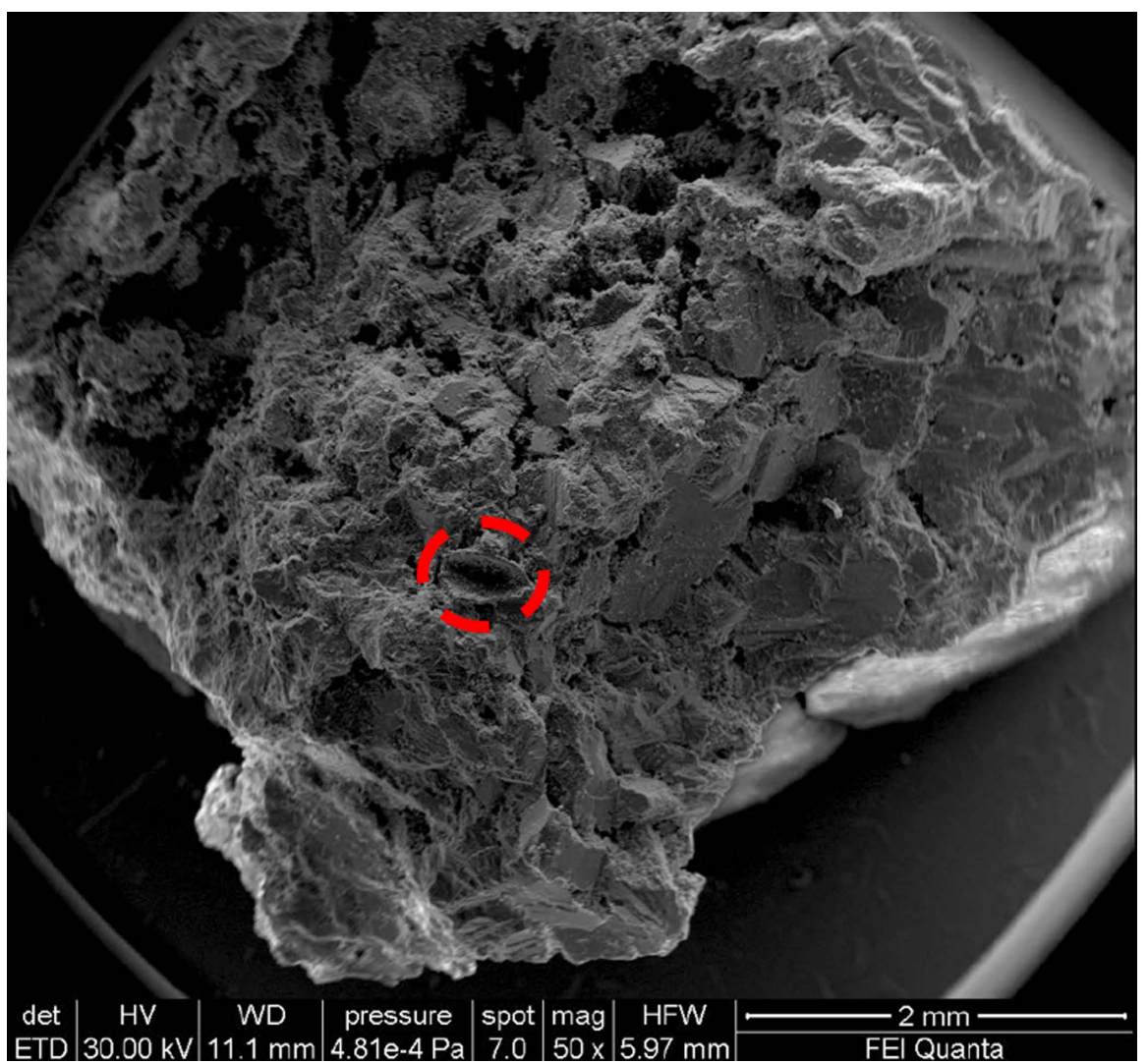

Figure 17. SEM photomicrograph of the sample PO 9 of mortar. The red circle highlights a microfossil fragment.

\subsubsection{Mortar Density}

The tests on the mortar samples provided values of real density $\left(\rho_{r}\right)$ between 2.63 and $2.65 \mathrm{~g} / \mathrm{cm}^{3}$ (arithmetic average $2.64 \mathrm{~g} / \mathrm{cm}^{3}$ ) and of bulk density $\left(\rho_{b}\right)$ between 1.37 and $1.40 \mathrm{~g} / \mathrm{cm}^{3}$ (arithmetic average $1.39 \mathrm{~g} / \mathrm{cm}^{3}$ ) (Table 4). These values are consistent with the mineralogical composition of the mortar (Table 3).

Table 4. Values of the real density $\left(\rho_{r}\right)$ and bulk density $\left(\rho_{b}\right)$ of the mortar samples.

\begin{tabular}{ccc}
\hline Sample & $\begin{array}{c}\rho_{r} \\
\left(\mathrm{~g} / \mathrm{cm}^{3}\right)\end{array}$ & $\begin{array}{c}\rho_{b} \\
\left(\mathrm{~g} / \mathrm{cm}^{3}\right)\end{array}$ \\
\hline PO 9 & 2.65 & 1.40 \\
PO 10 & 2.63 & 1.37 \\
PO 11 & 2.64 & 1.39 \\
Arithmetic average & 2.04 & 1.38 \\
Standard deviation & 0.008 & 0.012
\end{tabular}

The results of the macroscopic and microscopic investigations on the mortar suggest that it is characterized by a very homogeneous composition, and, for its production, the lime was obtained (Karkanas, 2007; Stoops et al., 2017; Cortéz Pérez et al., 2018; Montana et al., 2018) by calcination at about $1000^{\circ} \mathrm{C}$ of the TRV phytoclastic travertine (samples PO 3 and PO 4), while the sandy material 
of the aggregates, due to the very limited availability of sand in alluvial deposits ("at" and "b"; Figure 3), was obtained by grinding the ACP Sandstones (samples PO 5 and PO 6). This mortar perfectly cemented the stone materials of the walls, allowing the original architectural and structural elements of the bridge to still be used actually.

\subsubsection{Mechanical Properties of the ACP Sandstone}

The uniaxial compression tests of the POS 1 and POS 2 sandstone cores and the tensile tests of the POS 3 and POS 4 cores showed failure values ranging, respectively, between 370.50 and $309.70 \mathrm{~kg} / \mathrm{cm}^{2}$ (arithmetic average $340 \mathrm{~kg} / \mathrm{cm}^{2}$ ) and between 12.82 and $10.76 \mathrm{~kg} / \mathrm{cm}^{2}$ (arithmetic average $11.79 \mathrm{~kg} / \mathrm{cm}^{2}$ ) (Table 5). These values suggest that the sandstone has a medium-high consistency (Tanzini, 2010) and, therefore, is a very good substrate for the bridge foundations.

Table 5. Mechanical characterization of the ACP Sandstone by uniaxial compression and tensile tests.

\begin{tabular}{|c|c|c|c|c|c|c|c|}
\hline \multicolumn{8}{|c|}{ Uniaxial compression test } \\
\hline Core & $\begin{array}{l}\text { Lenght } \\
(\mathrm{cm})\end{array}$ & $\begin{array}{l}\text { Average } \\
\text { diameter } \\
(\mathrm{cm})\end{array}$ & $\begin{array}{l}\text { Controlled } \\
\text { load (kg) }\end{array}$ & $\begin{array}{l}\text { Cor } \\
\text { are }\end{array}$ & $\begin{array}{l}\text { sed } \\
\left.a^{2}\right)\end{array}$ & $\begin{array}{c}\text { Failure } \\
\text { stress } \\
(\mathrm{kN})\end{array}$ & $\begin{array}{c}\text { Compressive } \\
\text { strength }\left(\mathrm{kg} / \mathrm{cm}^{2}\right)\end{array}$ \\
\hline POS 1 & 9.5 & 9.5 & 1630 & & & 262.7 & 370.50 \\
\hline POS 2 & 9.6 & 9.5 & 1640 & & & 219.4 & 309.70 \\
\hline $\begin{array}{l}\text { Arithmetic } \\
\text { average }\end{array}$ & & & & & & & 340.1 \\
\hline $\begin{array}{l}\text { Standard } \\
\text { deviation }\end{array}$ & & & & & & & 30.4 \\
\hline \multicolumn{8}{|c|}{ Tensile test } \\
\hline Core & \multicolumn{2}{|c|}{$\begin{array}{l}\text { Length } \\
(\mathrm{cm})\end{array}$} & \multicolumn{2}{|c|}{$\begin{array}{l}\text { Average diameter } \\
\qquad(\mathrm{cm})\end{array}$} & \multicolumn{2}{|c|}{$\begin{array}{l}\text { Failure stress } \\
\qquad(\mathrm{kN})\end{array}$} & $\begin{array}{l}\text { Tensile strength } \\
\left(\mathrm{kg} / \mathrm{cm}^{2}\right)\end{array}$ \\
\hline POS 3 & \multicolumn{2}{|c|}{9.5} & 9.5 & & \multicolumn{2}{|c|}{17.79} & 12.82 \\
\hline POS 4 & \multicolumn{2}{|c|}{9.5} & 9.5 & & \multicolumn{2}{|c|}{15.68} & 10.76 \\
\hline $\begin{array}{c}\text { Arithmetic } \\
\text { average }\end{array}$ & & & & & & & 11.79 \\
\hline $\begin{array}{l}\text { Standard } \\
\text { deviation }\end{array}$ & & & & & & & 1.03 \\
\hline
\end{tabular}

\section{Discussion}

The geological and geomorphological setting, the historical data from the archives, the description of the current state of the POB, and the materials used for its construction suggest the following main topics as crucial points for the POB origin: 1) the construction techniques of Roman bridges in Campania; 2) the modifications of architectural and structural elements of the bridge over time; 3 ) the dating of the bridge; 4) the presence of remains attributable to a Roman age bridge in the area of the SVB, in relation to the layout of the old Appian Way. 


\subsection{Construction Techniques of Roman Bridges in Campania}

Galliazzo (1995) proposes to classify Roman bridges also based on materials and construction techniques, indicating the Italic type characterized by face with opus quadratum and internal structure with masonry work, the Valdostan type with an arch or twin arches, the Severian type which is an updated version of the first type, and the Campanian type built with masonry and face in small apparatus including opus testaceum and/or opus mixtum with alternating brick beds and opus reticulatum beds, and ornamental complement of opus vittatum or vittatum mixtum. This Author recognizes in the province of Avellino the presence of the Roman bridges of Casalbore (Santo Spirito and Ponticello), Luogosano and San Sossio Baronia. According to Aveta et al. (2012) the face of the Roman bridges of Campania is often built by the opus testaceum (bricks), opus mixtum, opus vittatum and vittatum mixtum.

Therefore, in addition to what is indicated by Galliazzo (1995) and Aveta et al. (2012), the material survey suggests that for the construction of the POB on the Ofanto River in the province of Avellino in Campania were also used the techniques of the opus quadratum and opus incertum.

\subsection{Modifications of the Architectural and Structural Elements of the Bridge over Time}

The only works documented and carried out on the bridge are those approved by the Provincial Council of Principato Ultra in 1856-1860. These works have not substantially modified the original structure of the bridge. Moreover, further restoration, modification, reconstruction and consolidation works were carried out for the construction of the national road SS 401 dir and its connection to the bridge, and as a consequence of the earthquakes of July 23, 1930 and November 23, 1980. Unfortunately, there is no documentation of these works. Therefore, the conditions of the architectural and structural elements of the bridge prior to the current ones (Figure 6 and Figure 7) are documented only by the photos of De Lorenzo (1906), Guarini (1909), Gardner Collection (Castrianni, 2013), Buglione (1929), Iacobone (1935). The clearest photos are those of the early 1990s by De Lorenzo (1906) (Figure 18(a)) and Gardner Collection (Castrianni, 2013) (Figure 18(b)), which show the bridge in its substantial integrity: the longitudinal profile of the bridge is characterized by an asymmetrical curvilinear trend with a slight slope towards both sides of the Ofanto River. Therefore, it is possible to compare the conditions of the architectural and structural elements of the bridge in the photos of De Lorenzo (1906) (Figure 18(a)) and the Gardner Collection (Castrianni, 2013) (Figure 18(b)) with those of today (Figure 6) in order to highlight the changes that took place between the early 1900s and the present time. The photo of De Lorenzo (1906) (Figure 18(a)) shows "the ancient Pietra dell'Olio Bridge on the Ofanto River near Aquilonia", taken from the left bank of the Ofanto River (NW, down-stream) with gravelly alluvial deposits. The structure of the bridge appears with the arches 1 and 2, the buttresses and the north- 
western abutment, partially covered by the weed vegetation, in which the masonry is shown on the right, the arch 3 covered by the weed vegetation, and the southeastern abutment whose masonry shows a square opening probably attributable to a rainwater discharge window. In the photo of the Gardner Collection, taken from the left bank of the Ofanto River (NW, up-stream), the bridge shows the three arches, the buttresses, the cutwaters, the abutments, and the ACP Sandstone in the background.
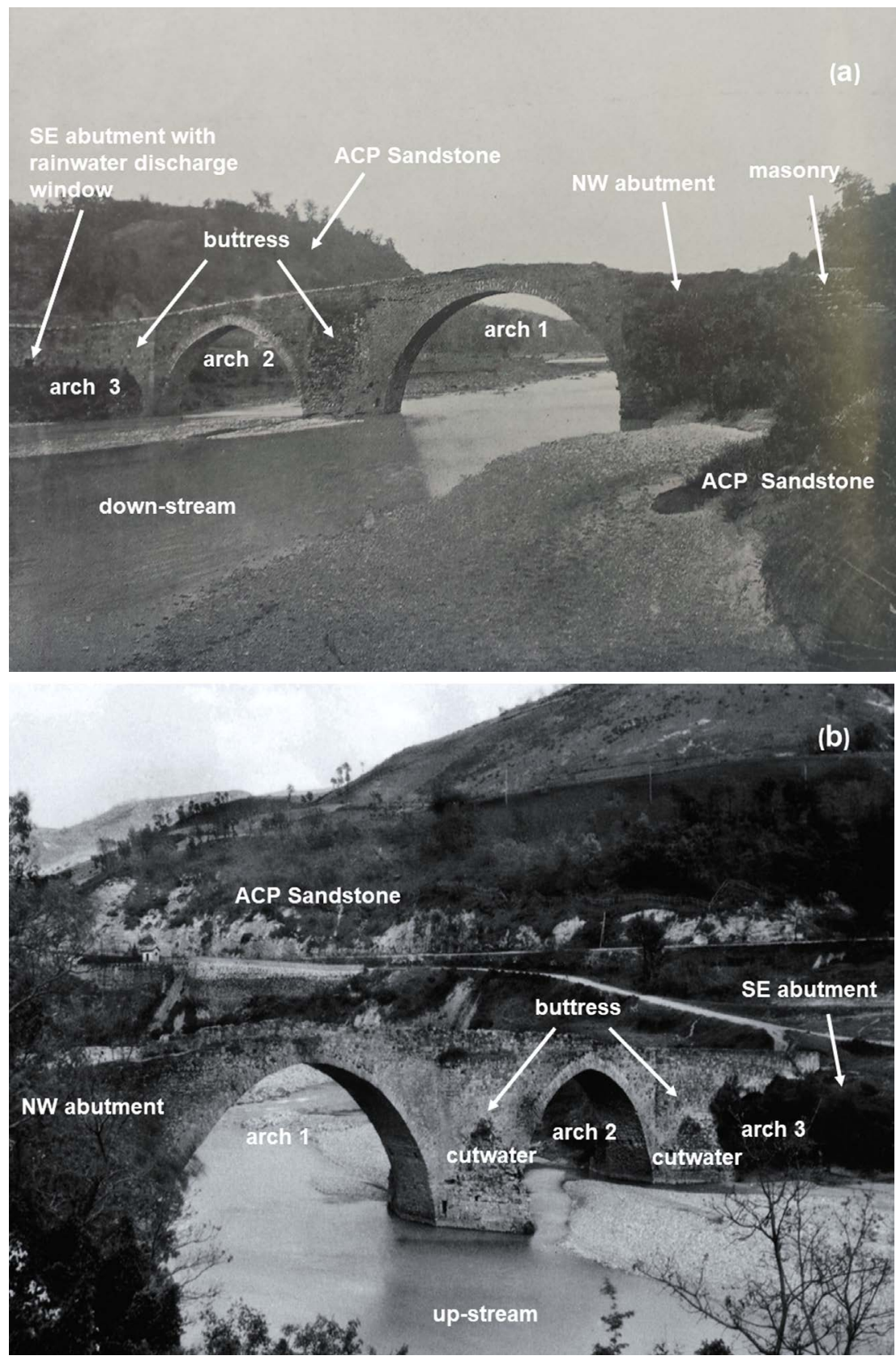

Figure 18. The POB façade in the photo of De Lorenzo (1906) (a), taken from the left bank of the Ofanto River (northwest, down-stream) and in the photo of the Gardner Collection (Castrianni, 2013) (b), taken from the left bank of the Ofanto River (northwest, up-stream). The arch 3 is covered by the weed vegetation in both photos. 
Comparison of Figure 18 with Figure 6 shows that the arch 3 is always covered by the weed vegetation and the following changes have occurred between the early 1900s and the present time.

$>$ The wall over the arch 3 in the photo of De Lorenzo (1906) (Figure 18(a)) does not appear in the photo of the current state of this arch (Figure 6(a)). This lack is due to two fundamental interventions: 1) the construction of the national road SS $401 \mathrm{dir}$, which involved a significant excavation of the ACP Sandstone (Figure 18(b)) and subsequently the connection of the road to the bridge with the consequent necessary modification of its southeastern abutment (MOASEs); 2) the consolidation works using the RDB pre-stressed reinforced concrete beams (AASEs; Figure 6 and Figure 7), and the works for the reconstruction of the arch 1 (RCASEs; Figure 7), probably after the earthquakes of July 23, 1930 and November 23, 1980. These interventions have also involved the modification of the asymmetrical curvilinear longitudinal profile of the bridge, which currently shows a linear profile, whose altitude is lower than the original one.

$>$ The northwestern abutment, the arches 2 and 3 with their relieving arches, the spandrel walls of arch 3 and the piers are original structures (OASEs; Figure 7), while the spandrel walls of arch 2, the buttresses and the cutwaters are restored (RASEs), and the arch 1 has been reconstructed (RCASEs; Figure 7).

\subsection{Dating of the Bridge}

For the dating of the bridge, we refer to the technique of construction of the arches 2 and 3 by the opus incertum in small apparatus, described in the monumental work of Lugli (1957), who, confirming the ideas of Blake (1947), distinguishes three "manners" to operate. In the first type, the stones with very different shapes and volumes are placed in a chaotic manner with abundant mortar (therefore they are not in contact) and the external surface is not leveled. In the second type, there is a better levelling of the external surface, less mortar of higher quality and greater contacts between stones with round and polyhedral shapes. The third type is characterized by the careful choice of stones and the installation according to their specific lithologies. The chronological difference between these different types is considered by the Author a way for the differentiation, because it depends on the availability of stone material, the type of structure to be built and the skill of the workers. Three periods are distinguished as follows: 1) between the end of the third century and $100 \mathrm{BC}$ for the first and second "manner"; 2) from 100 BC to 55 BC for the second and third "manner"; 3) from $55 \mathrm{BC}$ to the late empire (pseudo-uncertain; mixed with brick).

Subsequently also O'Connor (1993), Galliazzo (1995) and Adams (2011), confirming the ideas of Blake (1947) and Lugli (1957), believe that the technique in small apparatus of opus incertum achieves maximum development between the II and I century BC as a particular form of opus caementicium in order to obtain a functional and pleasant external face of a concrete wall. This type of masonry 
was used in the following bridges of Lazio and Marche (central Italy) and Campania (southern Italy) (Galliazzo, 1995):

$>$ the Sepolcri Bridge and probably the nearby Valerio Bridge built on the Aniene River near Tivoli (Lazio) in the first half of the I century BC;

$>$ the Viaduct of Sperlonga (Lazio) was built to connect the villa of Tiberius to the sea at the beginning of the I century BC;

$>$ the bridge over the confluent of the Chienti River in Pieve Torina (Marche) on the original Flaminia Way built in the I century BC;

$>$ the Latrone Bridge of the via Latina in Capriati al Voltuno (Campania) on the homonymous river of probable late republican age;

$>$ the Diavolo Bridge built partly in the III-II century BC, partly in the I century BC about $2 \mathrm{~km}$ east of Faicchio (Campania) on the Latina Way.

Further examples of Roman bridges, showing architectural and structural elements very similar to those of the POB with walls in small apparatus, are those of Pontaujard, Montbrison-sur-Lez Villeperdrix and Pont-de-Barret, Drôme sur le Roubion in France, dated between the II and I century BC (Barruol et al., 2011). Therefore, the construction technique by opus incertum and its use for many bridges in Italy and France suggests that the POB was built in the period between the II and the I century BC.

\subsection{The Area of the SVB}

Since it is crucial to establish where the layout of the old Appian Way crossed the Ofanto River by means of a bridge to reach Venosa, the following should be kept in mind about the SVB. 1) According to Pratilli (1745) this bridge has been "repeatedly rebuilt several times over the years and due to the many wars that occurred in past centuries". 2) Subsequently also Ashby (1916-1917) reports that "we have not been able to recognize in this bridge, nor in the others that cross the Ofanto River in this part of its course, any construction remains dating back to before the Middle Ages". 3) According to Fortunato (1968) this bridge was demolished by the floods of the Ofanto River. 4) Quilici (1989) describes this bridge as an "earlier structure with six beautiful arches of the Middle Ages". However, most of the Authors, including those mentioned above, argued that the layout of the old Appian Way went along the SVB (Figure 2), located about $15 \mathrm{~km}$ north of the POB. Therefore, we carried out a detailed inspection of the SVB area, which showed the following:

$>$ the Ofanto River valley is very wide (about $150 \mathrm{~m}$ ) and the slopes of the river consist of the Varicolored Clays Formation subject to frequent and massive landslides, suggesting that the geomorphological conditions of the site and the hydraulic ones of the Ofanto River are, especially in Roman times, much less favorable for the construction of a bridge, compared to those of the area of the POB;

$>$ the structures of the SVB are not of Roman age and there is no trace of structures of this age in the surrounding that can be referred to a bridge. 
Consequently, the hypothesis that the SVB is connected to the layout of the old Appian Way is not supported by any objective and solid evidence.

\section{Conclusion}

The discussion of all the data of the POB allows us to propose the following conclusions.

Structural elements, technique, period of construction of the bridge. The masonry bridge (pons lapideus) consists of 18 OASEs (the northwestern abutment, the arches 2 and 3, their relieving arches and piers, the spandrel walls of the arch 3 , and the direct foundations), 12 RASEs (the spandrel walls of the arch 2, the buttresses, two cutwaters), 1 MASE (the southeastern abutment), and 4 RCASEs (the arch 1, the roadway, and the parapet walls). In addition, there are the four $\mathrm{RDB}$ pre-stressed reinforced concrete beams between the southeastern abutment and the arches 2 and 3, indicated as AASEs. The OASEs are built using the technique of the opus quadratum and opus incertum. Therefore, based on the technique of opus incertum, and taking into account the examples of bridges with this type of masonry located in Lazio and Marche (central Italy), Campania (southern Italy), and at Pontaujard, Montbrison-sur-Lez Villeperdrix and Pont-de-Barret, Drôme sur le Roubion in France, the dating of the bridge can be referred to the period between the II and the I century BC.

State of conservation of the bridge. Despite the restoration, consolidation and reconstruction of some architectural and structural elements, the original ones (OASEs) are still fairly well preserved.

Classification of the bridge according to the number, profile, width of arches. The bridge consists of three round arches with diminishing light from arch 1 to arch 3.

Suitability of the site for the construction of the bridge. For the design of a bridge that crosses the Ofanto River between Conza della Campania and the SVB, the most suitable site is the one where the POB was built. In fact, the river valley is about $50 \mathrm{~m}$ wide, the slopes made up of the ACP Sandstone are free of landslides and a very good substrate for the bridge foundations, while in the area of the SVB the river valley not only is wider (about $150 \mathrm{~m}$ ), but its slopes, which include the Varicolored Clays Formation, are subject to frequent and massive landslides.

Importance of the bridge. The masonry bridge shows the following characteristics: considerable dimensions, original longitudinal profile with asymmetrical curvilinear trend, three round arches, piers with a thickness of $4.30 \mathrm{~m}$, roadway $103.60 \mathrm{~m}$ long and $4.30 \mathrm{~m}$ wide, which could allow the wagons to transit in two ways. Therefore, the bridge had to be at the service of a very important public road.

In conclusion, the present research is allowed to achieving three goals:

$>$ to establish, based on the geological and geomorphological setting, that the most suitable site for the construction of a bridge over the Ofanto River be- 
tween Conza della Campania and the SVB in Roman times is the one where the $\mathrm{POB}$ was built;

the POB is identified with the Pons Aufidi in agreement with the southern layout of the old Appian Way between Mirabella Eclano (Aeclanum) and Venosa (Venusia), which is the shortest, most convenient in terms of design and construction, and therefore the most reliable. Consequently, the hypothesis of the northern layouts, which cross the Ofanto River by the SVB, is no longer sustainable;

the construction technique of the POB helps to improve the knowledge of Roman bridge engineering, particularly in Campania.

In order to improve the state of conservation of the POB, we suggest to the Archaeological Superintendence of Campania, territorial authority responsible for the management of archaeological assets, to prepare a study aimed at maintenance and safeguard of the bridge by some suggestions.

Periodic checks of the following elements: conditions of stone materials and masonry mortar with interventions aimed at restoring deteriorated parts, weed and climbing vegetation that covers extensive surfaces of the structures, thermal and hydrological variations, washing away action, fire, salt efflorescence, chemical aggression from pollutants, weight of bearing walls and accessory parts, transit of vehicles, ordinary and accidental hydrodynamic flow of the river, sinking and undermining of the setting planes, subsidence of foundations, seismic effects. In this regard, the weight analysis is suitable to evaluate the weights of the load-bearing walls and accessory parts. Such an investigation, carried out by the core drilling and the determination of their volumes, specific weights and centers of gravity, is particularly significant for the check of limit conditions of the bridge.

Because the bridge is located in an area with high seismic hazard, the non-destructive sonic tests of materials are aimed at modeling the structural behavior for seismic action, which requires the knowledge of the mechanical distribution of deformation and resistance of materials, in particular of the walls.

\section{Acknowledgements}

The research was supported by the Associazione Nazionale per gli Interessi del Mezzogiorno d'Italia (ANIMI). The authors are grateful to Armando Marano and Angelo Pizzella who produced the images of the bridge taken by the drones; Giovanni Savarese and Raffaele Miranda who took care of the graphics of the figures; Celestino Grassi ${ }^{2}$ for the useful discussion on the structures of the bridge.

\section{Conflicts of Interest}

The authors declare no conflicts of interest regarding the publication of this paper.

${ }^{2}$ Died on September 24, 2019. 


\section{References}

Adams, J. P. (2011). L'arte di costruire presso i romani-Materiali e tecniche (369 p.). X edizione. Longanesi.

Alvisi, G. (1970). La viabilità romana della Daunia. Società di Storia Patria per la Puglia, Documenti e monografie, XXXVI.

American Geological Institute (AGI) (2005). Glossary of Geology (5th ed., 779 p.). American Geological Institute.

APAT-Agenzia per la Protezione dell'Ambiente e per i Servizi Tecnici-Dipartimento Difesa del Suolo-Servizio Geologico d'Italia (2005). Carta Geologica d'Italia. Scala 1:250,000. S.E.L.C.A.

Ashby, T. (1916-1917). Le vie Appia e Traiana. Bollettino dell'Associazione Archeologica Romana, VI-VII, 10-23.

ASTM (2014). Standard Test Method for Compressive Strength and Elastic Moduli of Intact Rock Core Specimens under Varying States of Stress and Temperatures. ASTM International.

Aveta, A., Monaco, L. M., \& Aveta, C. (2012). La conservazione dei ponti storici in Campania (246 p.). Edizioni Scientifiche Italiane.

Barruol, G., Fiches, J.-L., \& Garmy, P. (2011). Ponte Routiers en Gaulle Romaine (685 p.). Revue Archeologique de Narbonnaise. Supplement 41.

Blake, M. E. (1947). Ancient Roman Construction from the Prehistoric Period to Augustus (421 p.). Carnegie Institution of Washington.

Buglione, V. (1929). Monteverde. Sulle reliquie pelasgiche dell'area “Aquilonia”, IrpinoSannita (anno 293 a. C.), nell'Evo medio e moderno (anno 500-1929) (384 p.). Melfi.

Capezzuoli, E., \& Gandin, A. (2004). I "travertini” in Italia: proposta di una nuova nomenclatura basata sui caratteri genetici. Il Quaternario, 17, 273-284.

Capezzuoli, E., Gandin, A., \& Pedley, H. M. (2014). Decoding Tufa and Travertine (Fresh Water Carbonates) in the Sedimentary Record. The State of the Art. Sedimentology, 61, 1-21. https://doi.org/10.1111/sed.12075

Carluccio, M. (2013). Tecniche di costruzione dei ponti romani sull'Ofanto. In La via delle aquile nella terra dei lupi, Atti del Convegno, Conza della Campania 28 agosto 2012 (pp. 81-88). A cura di C. Grassi.

Castagnoli, F. (1969). Il tracciato della via Appia. Capitolium, 44, 77-100.

Castrianni, L. (2013). Ponte Pietra dell'Oglio. In La Regina Viarum e la via Traiana. Da Benevento a Brindisi nelle foto della collezione Gardner (pp. 100-101). British School at Rome Archive, 11. A cura di L. Castrianni \& G. Ceraudo.

Centamore, E., Lanari, G., Chiocchini, U., Santagati, G., \& Jacobacci, A. (1971). Geologia della zona nord-orientale del Foglio 187 "Melfi" (Lucania). Bollettino del Servizio Geologico d'Italia, XCI, 113-148.

Cera, G. (2011). La via Appia dans les Pouilles (Italie). In Les voies romaines autour de la Méditerranée (Dossiers d'archéologie, 343) (pp. 32-37). A cura di S. Crogiez-Pétrequin \& J.L. Fiches.

Ceraudo, G. (2011). L’Apulie et la Calabre (Italie), II ${ }^{\mathrm{e}}$ région augustéenne. In Les voies romaines autour de la Méditerranée (Dossiers d'archéologie, 343) (pp. 26-31). A cura di S. Crogiez-Pétrequin \& J.L. Fiches.

Ceraudo, G. (2019). La via Appia tra Campania e Puglia. In M. L. Marchi (Ed.), Via Appia Regina Viarum. Atti del Convegno Melfi-Venosa 3-4 Maggio 2017 (pp. 117-132). Osanna Edizioni. 
Chiocchini, U., Grassi, C., \& Vistoli, F. (2016). Contributo alla determinazione del tracciato della via Appia antica tra Aeclanum e Venusia. Atti e Memorie della Società Magna Grecia, Quarta Serie VI (2014-2015), 65-108.

Columbu, S., Lisci, C., Sitzia, F., Lorenzetti, G., Lezzerini, M., Pagnotta, S., Raneri, S., Legnaioli, S., Palleschi, V., Gallello, G., \& Adembri, B. (2018). Mineralogical, Petrographic, Physical-Mechanical Study of Roman Construction Materials from the Maritime Theatre of Hadrian's Villa (Rome, Italy). Measurements, 127, 264-276. https://doi.org/10.1016/j.measurement.2018.05.103

Consiglio Nazionale delle Ricerche (1990). Progetto Finalizzato Geodinamica. Structural Model of Italy. S.E.L.C.A., Firenze.

Cortéz Pérez, J., de Sanjosè Blasco, J. J., Atkinnson, D. J., \& del Rio Pérez, L. M. (2018). Assessment of the Structural Integrity of the Roman Bridge of Alcantara (Spain) Using the TLS and GPR. Remote Sensing, 10, 387. https://doi.org/10.3390/rs10030387

D’Argenio, B., \& Ferreri, V. (1987). A Brief Outline of Sedimentary Models for Pleistocene Travertine Accumulation in Southern Italy. Rendiconti online della Società Geologica Italiana, 9, 167-170.

D’Argenio, B., \& Ferreri, V. (1988). Ambienti di deposizione e litofacies dei travertini quaternari dell'Italia centro-meridionale. Memorie della Società Geologica Italiana, 41, 861-868.

D’Argenio, B., Ferreri, V., \& Anzalone, E. (2013). Travertines of Central and Southern Italy. Rendiconti online della Società Geologica Italiana, 27, 4-9. https://doi.org/10.3301/ROL.2013.16

De Lorenzo, G. (1906). Venosa e la regione del Vulture (La Terra d'Orazio) (116 p.). Collezione di Monografie Illustrate. Italia Artistica, 24. Istituto d'Arti Grafiche.

De Luca, F. (2003). La via Appia in Puglia. In Sulla via Appia da Roma a Brindisi. Le fotografie di Thomas Ashby (1891-1925) (p. 151). British School at Rome Archive, 6, a cura di S. Le Pera Buranelli \& R. Turchetti.

Del Lungo, S. (2013). Topografia e antichità della via Herculia in Basilicata, tra leggenda e realtà. In Lungo la via Herculia. Storia, territorio, sapori (pp. 15-89). A cura di C.A. Sabia \& R. Sileo.

Della Portella, I. (2003). Da Benevento a Brindisi. In Via Appia antica (pp. 146-185). A cura di I. Della Portella, San Giovanni Lupatoto (VR).

Flammia, P. A. F. (1995). La Tabula Peutingeriana. Storia e descrizione di una carta stradale dell'impero romano. Civiltà Altirpina, 6, 29-47.

Ford, T. D., \& Pedley, H. M. (1996). A Review of Tufa and Travertine Deposits of the World. Earth Science Review, 41, 117-175. https://doi.org/10.1016/S0012-8252(96)00030-X

Fornaro, A. (2000). Riflessioni sul percorso della via Appia tra Benevento e Taranto. Rivista di Topografia Antica, 10, 301-308.

Fortunato, G. (1968). Badie, feudi e baroni della valle di Vitalba (Volume 1, Edizione Prima, 276 p.). P. Lacaita.

Galliazzo, V. (1995). I ponti romani (Volume 1, 761 p., Volume 2, 447 p.). Canova.

Gandin, A. (2013). Classificazione genetica, caratteri petrologici distintivi e valori isotopici correlati di calcari incrostanti depositi da acque scorrenti (Travertini-Calcareous TufaSpeleotemi). Rendiconti online della Società Geologica Italiana, 27, 10-30. https://doi.org/10.3301/ROL.2013.17

Gandin, A., \& Capezzuoli, E. (2008). Travertine versus Calcareous Tufa: Distinctive Petrologic Features and Stable Isotope Signature. Il Quaternario. Italian Journal of Quaternary Sciences, 21, 125-136. 
Gazzola, P. (1963). Ponti romani, contributo ad un indice sistematico con studio critico bibliografico. Volume I. Volume II (220 p.). Leo S. Olschki Editore.

Gençer, U., \& Turan, H. (2017). The Masonry Techniques of a Historical Bridge in Hypokremos (Içmeler). METU JFA/1, 34, 187-207.

Geological Society of America (1991). Rock-Color Chart. Geological Society of America.

Ghilardi, M., \& Desruelles, S. (2009). Geoarchaeology: Where Human, Social and Earth Sciences Meet with Technology. Sapiens, 2, 1-9.

Giannandrea, P. (2004). I depositi terrazzati nell'alta valle del fiume Ofanto (Foglio 451 "Melfi", Appannino Campano-Lucano). Il Quaternario. Italian Journal of Quaternary Sciences, 17, 511-521.

Gilbert, A. S. (2017). Encyclopedia of Geoarchaeology (1046 p.). Springer.

Grassi, C. (2013). Dalle Mefite a Venosa lungo la Capostrada e Conza. In La via delle aquile nella terra dei lupi. Atti del Convegno, Conza della Campania 28 agosto 2012 (pp. 71-80). A cura di C. Grassi.

Grasso, G. (1893). Studi di storia antica e di topografia storica, 1. Ariano (AV).

Guarini, G. B. (1909). Il ponte romano della via Erculea e la masseria regia di Federico II a S. Nicola dell'Ofanto. Rivista d'Italia, 12, 414-429.

Hughes, T. G., \& Blackler, M. J. (1997). A Review of the UK Masonry Arch Assessment Methods. Proceedings of the Institution of Civil Engineers, 122, 301-315. https://doi.org/10.3301/ROL.2013.17

I.S.R.M. (1994). Raccomandazioni per la determinazione della resistenza a compressione monoassiale e della deformabilità dei materiali rocciosi. Rivista Italiana di Geotecnica, 3, 247-251.

Iacobone, N. (1935). La patria di Orazio, Venusia, centro stradale dell'Apulia e della Lucania. Japigia, 6, 307-332.

Imbriale, P. (2014). I travertini quaternari della Campania: Caratteri sedimentologici, geochimici e ipotesi genetica (240 p.). Università degli Studi di Napoli "Federico II". Dottorato di Ricerca in Scienze della Terra-XXV Ciclo.

Inglese, C., \& Paris, L. (2020). Arte e tecnica dei ponti romani in pietra (213 p.). Sapienza Università Editrice.

Ippolito, F., \& Paganelli, F. (1984). Il dissesto idrogeologico della Basilicata: situazioni e interventi (96 p.). Quaderni della Cassa per il Mezzogiorno, 9.

Istituto Superiore per la Protezione e la Ricerca Ambientale-Servizio Geologico d'Italia (In Print-a). Foglio 451 Melfi della Carta Geologica d'Italia alla scala 1:50.000.

Istituto Superiore per la Protezione e la Ricerca Ambientale-Servizio Geologico d'Italia (In Print-b). Foglio 450 S. Angelo dei Lombardi della Carta Geologica d'Italia alla scala 1: 50.000 .

Jannacchini, A. M. (1889). Topografia storica dell'Irpinia, I (226 p.). Tipografia di Gennaro Maria Priore. Napoli.

Johannowsky, W. (1996). Baronia: perché il Museo. Vicum, 14, 5-7.

Karkanas, P. (2007). Identification of Lime Plaster in Prehistory Using Petrographic Methods: A Review and Reconsideration of the Data on the Basis of Experimental and Case Studies. Geoarchaeology, 22, 775-796. https://doi.org/10.1002/gea.20186

Lariccia, L. (2015). Aufidus: Note storico-filologiche. In L'Ofanto dagli impeti di vortici e di creste. Letteratura, memoria, paesaggio (pp. 83-92). A cura di A. Nannariello, Nusco $(\mathrm{AV})$. 
Lenormant, F. (1883). Atravers l'Apulie et la Lucane. Notes de voyage, I. Paris.

Leonardi, G. (2017) S.v. Geoarcheologia. In R. Francovich, \& D. Manacorda (Eds.), Dizionario di Archeologia (pp. 155-159). Editori Laterza.

Lugli, G. (1952). Osservazioni sulle stazioni della via Appia da Roma ad Otranto. In Beiträge zur älteren europäischen Kulturgeschichte (pp. 276-293). Festschrift für Rudolf Egger, I. A cura di G. Moro, Klagenfurt.

Lugli, G. (1957). La tecnica edilizia romana. Volume I. Volume II Tavole. Giovanni Bardi Editore.

Lugli, G. (1963). Il sistema stradale della Magna Grecia. In Vie di Magna Grecia. Atti del secondo Convegno di studi sulla Magna Grecia, Taranto, 14-18 ottobre 1962, 23-37.

Mannert, C. (1823). Geographie von Italia, nebst den Inseln Sicilia, Sardinia, Corsica etc. Geographie der Griechen und Romer, IX. 2, Lipsiae.

Marchi, M. L. (2019a). La via Appia e l'espansione nel sud est d'Italia. In M. L. Marchi (Ed.), Via Appia Regina Viarum (pp. 91-116). Atti del Convegno Melfi-Venosa 3-4 Maggio 2017.

Marchi, M.L. (2019b). Il cammino dei romani in Lucania: dall'Ofanto al Bradano. In M. L. Marchi (Ed.), Appia antica. La Regina Viarum in Lucania Dall'Ofanto al Bradano (pp. 54-118). Osanna Edizioni.

Marchi, M. L., \& Ferlazzo, G. (2015). La via Appia e le strade della romanizzazione. Nuovi dati sui percorsi dall'Irpinia alla Puglia. In Roma, strade e infrastrutture, città $e$ monumenti (Atlante tematico di topografia antica, 25) (pp. 133-148). A cura di L. Quilici \& S. Quilici Gigli.

Marra, F., Danti, A., \& Gaeta, M. (2015). The Volcanic Aggregate of Ancient Roman Mortars from the Capitoline Hill: Petrographic Criteria for Identification of Rome's "Pozzolans" and Historical Implications. Journal of Volcanology and Geothermal Research, 308, 113-126. https://doi.org/10.1016/j.jvolgeores.2015.10.007

Massaro, A. (1994). Avellino tra decennio e restaurazione nelle opere di Luigi Oberty ingegnere del Corpo Ponti e Strade (17 p.). Avellino, Grafic Wag.

Mommsen, T. (1848). Sulla topografia degli Irpini. Bollettino dell'Istituto di Corrispondenza Archeologica, 1, 4-13.

Montana, G., Randazzo, L., Ventura-Bordenca, C., Giarrusso, R., Baldassarri, R., \& Polito, A. M. (2018). The Production Cycle of Lime-Based Plasters in the Late Roman Settlement of Scauri, on the Island of Pantelleria, Italy. Geoarchaeology, 34, 631-647.

Morano T. (2003). La modifica del territorio e degli assetti urbani in Irpinia. De Angelis Editore.

O’Connor, C. (1993). Roman Bridges (VIII, 235 p.). Cambridge University Press.

Pedley, H. M. (1990). Classification and Environmental Models of Cool Freshwater Tuffs. Sedimentary Geology, 68, 143-154. https://doi.org/10.1016/0037-0738(90)90124-C

Pedley, H. M. (2009). Tuffs and Travertine of the Mediterranean Region: A Testing Ground for Freshwater Carbonate Concepts and Development. Sedimentology, 56, 221-246. https://doi.org/10.1111/j.1365-3091.2008.01012.x

Pedley, H. M. (2014). Decoding Tufa and Travertine (Fresh-Water Carbonates) in the Sedimentary Record. The State of the Art. Sedimentology, 61, 1-21. https://doi.org/10.1111/sed.12075

Pisani Sartorio, G. (2003). Origini e vicende storiche. In D. Portella (Ed.), Via Appia antica, I (pp. 14-39). San Giovanni Lupatoto (VR).

Pollard, A. M. (1999). Geoarchaeology: An Introduction. In A. M. Pollard (Ed.), Geoar- 
chaeology: Exploration, Environments, Resources (pp. 7-14). Geological Society of London, N. 165. https://doi.org/10.1144/GSL.SP.1999.165.01.01

Pratilli, F. M. (1745). Della via Appia. Riconosciuta e descritta da Roma a Brindisi. Libri IV (576 p.). Napoli MDCCXLV. Sala Bolognese, Arnaldo Forni Editore, 1993.

Quilici, L. (1989). Via Appia: Dalla Pianura Pontina a Brindisi (107 p.). Palombi Editori.

Quilici, L. (2004). La via Appia. Un percorso nella storia (128 p.). Viviani Editore.

Radke, G. (1981). Viae publicae romanae (429 p.). Edizione italiana. Cappelli Editore.

Rapp, Jr. G. R., \& Hill, C. L. (1998). Geoarchaeology: The Earth-Science Approach to Archaeological Interpretation. Yale University Press.

Romito, M. (1995). Guerrieri sanniti e antichi tratturi nell'alta valle dell'Ufita (160 p.). Collana Fonti archeologiche per la storia del Mezzogiorno medievale, 2. Laveglia \& Carlone Editore.

Schiattarella, M., Giannandrea, P., Principe, P., \& La Volpe, L. (In press). Note Illustrative della Carta Geologica d'Italia alla scala 1: 50.000. Foglio 451 Melfi.

Shahack-Gross, R. (2017). Archaeological Formation Theory and Geoarchaeology: Stateof-the-Art in 2016. Journal of Archaeological Science, 79, 36-43. https://doi.org/10.1016/j.jas.2017.01.004

Shillito, L.-M., Blong, J., Sawyer, A., \& Mackay, H. (2019). Introduction. Geoarchaeology from Landscapes to Material Culture: Papers from the 7th Developing International Geoarchaeology Conference. Geoarchaeology, 34, 377-379.

https://doi.org/10.1002/gea.21742

Sitzia, F., Beltrame, M., Columbu, S., Lisci, C., Miguel, C., \& Mirao, J. (2020). Ancient Restoration and Production Technologies of Roman Mortars from Monuments Placed in Hydrogeological Risk Areas: A Case Study. Archaeological and Anthropological Sciences, 12, 147.

Stazio, A. (1987). Via Appia. Da Roma a Brindisi attraverso Capua e Benevento (Itinerari turistico culturali nel Mezzogiorno, 2) (188 p.). Napoli. Edizioni del Sole.

Stoops, G., Canti, M. G., \& Kapur, S. (2017). Calcareous Mortars, Plasters and Floors. In C. Nicosia, \& G. Stoops (Eds.), Archaeological Soil and Sediment Micromorphology (pp. 189-199). John Wiley \& Sons, Ltd. https://doi.org/10.1002/9781118941065.ch23

Tanzini, M. (2010). Manuale del Geotecnico (519 p.). Dario Flaccovio Editore.

Tazzi, A. M. (1998). Le strade dell'antica Roma: Dal IV secolo a.C. al V secolo d.C. In Europa, Asia e Africa (229 p). Libreria Dedalo.

Troncone, G. (2013). La via Appia in Irpinia. In La via delle aquile nella terra dei lupi. Atti del Convegno, Conza della Campania 28 agosto 2012 (pp. 29-70). A cura di C. Grassi.

Vallario, A. (2001). Il dissesto idrogeologico in Campania (300 p.). CUEN s.r.l., Napoli.

Vistoli, F. (2019). Notula sulle stazioni itinerarie di Sub Romula e Pons Aufidi lungo la via Appia ofantina. In M. L. Marchi (Ed.), Via Appia Regina Viarum. Atti del Convegno Melfi-Venosa 3-4 Maggio 2017 (pp. 245-288). Osanna Edizioni. 